\title{
Contrasting geology in the Pocologan River and Long Reach areas: implications for the New River belt and correlations in southern New Brunswick and Maine
}

\author{
Susan C. Johnson \\ New Brunswick Department of Natural Resources \& Energy, Geological Surveys Branch, \\ P.O. Box 5040, Sussex, NB E4E 5L2, Canada
}

Date Received: June 12, 2001

Date Accepted: January 14, 2002

\begin{abstract}
The Pocologan River and Long Reach areas are situated in the New River belt, which comprises the westernmost exposures of Neoproterozoic rocks in southern New Brunswick. Previous mapping in the southwestern part of the New River belt indicated that Neoproterozoic and Cambrian rocks in the Pocologan River area are different from coeval strata in the Caledonia belt (Avalon zone sensu stricto) in the Saint John area. Recent mapping in the Long Reach area has shown that there are significant lithological changes across the Robin Hood Lake fault, which bisects the New River belt into northeastern (Long Reach) and southwestern (Pocologan River) segments. Neoproterozoic and Cambrian rocks in the Long Reach area are directly comparable to those in the Caledonia belt, demonstrating that the New River belt is composite.

Recent data have also shown that Early Cambrian volcanic activity in the Pocologan River area is broadly contemporaneous with epeirogenic events related to a major sequence boundary in the Avalonian cover sequence. This suggests that the northeastern and southwestern segments of the composite New River belt may have experienced a similar tectonic event, possibly as separate but adjacent continental fragments or as geographically isolated parts of one Gondwanan terrane. The lithological similarity of late Early to (?) Middle Cambrian quartzose sedimentary strata in the Pocologan River area to Middle Cambrian rocks in the St. Croix belt in Maine also supports the suggestion that the St. Croix belt is part of this composite terrane.
\end{abstract}

Les secteurs de la rivière Pocologan et de Long Reach sont situés dans la ceinture de New River, qui englobe les affleurements les plus à l'ouest des roches du Protérozoïque supérieur du Sud du Nouveau-Brunswick. Des travaux de cartographie antérieurs dans le sud-ouest de la ceinture de New River ont révélé que les roches du Protérozoïque supérieur et du Cambrien du secteur de la rivière Pocologan constituaient des exemplaires uniques de strates contemporaines de la ceinture de Caledonia (zone d'Avalon au sens strict) dans la région de Saint-Jean. Des travaux de cartographie récents dans le secteur de Long Reach ont révélé des changements lithologiques marqués à travers la faille du lac Robin Hood, qui subdivise la ceinture de New River en deux segments : les segments nord-est (Long Reach) et sud-ouest (rivière Pocologan). Les roches du Protérozoïque supérieur et du Cambrien du secteur de Long Reach sont directement comparables à celles de la ceinture de Caledonia, ce qui démontre que la ceinture de New River constitue une ceinture composite.

Des données récentes ont également révélé que l'activité volcanique du Cambrien inférieur dans le secteur de la rivière Pocologan a en gros été contemporaine aux phénomènes épirogéniques apparentés à une limite de séquence importante dans la séquence de couverture avalonnienne. Cela laisse supposer que les segments nord-est et sud-ouest de la ceinture composite de New River pourraient avoir été soumis à un phénomène tectonique analogue, possiblement en tant que fragments continentaux distincts mais adjacents ou de parties géographiquement isolées d'un terrane du Gondwana. La similarité lithologique des strates sédimentaires quartzeuses de la fin du Cambrien précoce au Cambrien moyen (?) dans le secteur de la rivière Pocologan avec les roches du Cambrien moyen de la ceinture de St. Croix au Maine appuie par ailleurs l'hypothèse que la ceinture de St. Croix fait partie de ce terrane composite.

Traduit par la rédaction

\section{INTRODUCTION}

Cambrian or older rocks in southern New Brunswick are exposed in four, northeast-trending belts, separated by major faults and/or Late Ordovician and younger rocks. Although the term terrane has been used to describe some of these blocks (e.g. Barr and White 1996a; White and Barr 1996; Fyffe et al. 1999) they are all herein referred to as belts for uniformity. From west to east they comprise the St. Croix belt, the New River belt, the Brookville belt and the Caledonia belt (Fig. 1). The term Avalon zone (sensu stricto) has been applied to the
Caledonia belt as it contains Cambrian-Ordovician strata that are part of the Avalonian cover sequence (Landing 1996). In New Brunswick, Neoproterozoic rocks are exposed in all of these belts except the St. Croix belt; however, rocks of probable Neoproterozoic age underlie equivalent strata in Maine (Tucker et al. 2001).

The Pocologan River and Long Reach areas are part of the New River belt, which is situated west of the Belleisle fault and east of the Back Bay - Wheaton Brook fault (Johnson and McLeod 1996). The New River belt is bordered to the east by Early Silurian arc-related volcanic and intrusive 


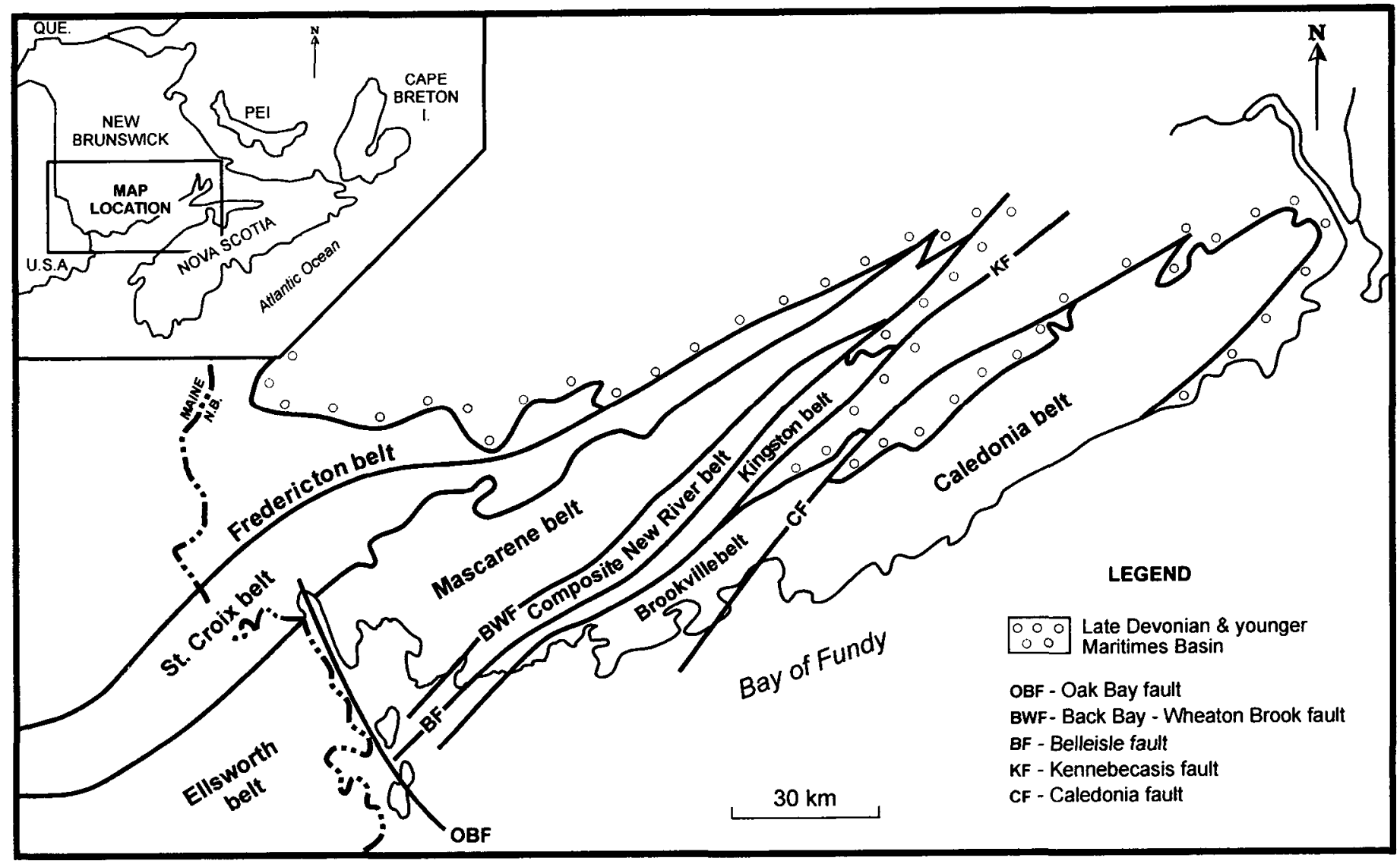

Fig. 1. Simplified regional map of southern New Brunswick and eastern Maine showing subdivision of major tectonic divisions.

rocks of the Kingston belt (Barr et al. 1999; Barr and White $2001 \mathrm{~b}$ ) and to the west by Early Silurian to Early Devonian volcanic and shallow marine sedimentary rocks of the Mascarene belt (Fyffe et al. 1999). In Maine, Silurian and Devonian rocks equivalent to the Mascarene belt are included in the Ellsworth belt (Fig. 1), which also contains rocks as old as Middle Cambrian and possibly older (Berry and Osberg 1989).

Based on detailed mapping in the Pocologan River area, Neoproterozoic and Cambrian rocks in the New River belt were considered to be distinct from those in Caledonia belt (Johnson and McLeod 1996). In an attempt to delineate map units to the northeast, 1:20,000-scale mapping was recently conducted in the Long Reach area (Fig. 2) (Johnson 2001b). The results of this mapping, combined with published radiometric data (Currie and McNicoll 1999; Johnson 2000, $200 \mathrm{lb}$ ), indicate that there are significant differences between lithostratigraphic and plutonic units in the Pocologan River and Long Reach areas across the Robin Hood Lake fault (Fig. 2). Cambrian sedimentary rocks east of the Robin Hood Lake fault can be precisely assigned to depositional sequences within the Avalonian cover sequence in the Saint John area, whereas Cambrian strata in the Pocologan River area cannot. This difference suggests that the New River belt is a composite belt, comprised of disparate segments juxtaposed along the Robin Hood Lake fault. Although only cursory mapping was carried out in the Beaver Harbour area (Fig. 2), these rocks are also considered to be broadly correlative with the Caledonia belt based on the presence of Middle Cambrian Avalonian fauna in this sequence (Landing 1996).

Recently published data, in particular the re-calibration of the Cambrian time scale (Landing et al. 1998; McKerrow and van Staal 2000), reveals that the volcanic rocks in the Pocologan River area are Early Cambrian, not Late Cambrian as originally thought (cf. Johnson and McLeod 1996). This paper reports the results of new and previous mapping in the New River belt combined with recently published geochronological data and sequence stratigraphy for the Avalonian cover sequence (e.g., Isachsen et al. 1994; Landing 1996; Landing and Westrop 1998; Landing et al. 1998). These data suggest that the differences exhibited by the Pocologan River segment do not necessarily imply a non-Avalonian origin for these rocks. The implications of this work with respect to recent tectonic models for southern New Brunswick are also discussed.

\section{GEOLOGY OF THE LONG REACH AREA}

The Long Reach area is located on the west side of the Long Reach of the Saint John River, approximately $25 \mathrm{~km}$ northwest of the city of Saint John (Fig. 3). The main access is by way of Highway 7 and Route 102. Neoproterozoic and Cambrian rocks are exposed in a narrow ( $<10 \mathrm{~km}$ wide) zone between the Belleisle and Wheaton Brook faults, where 


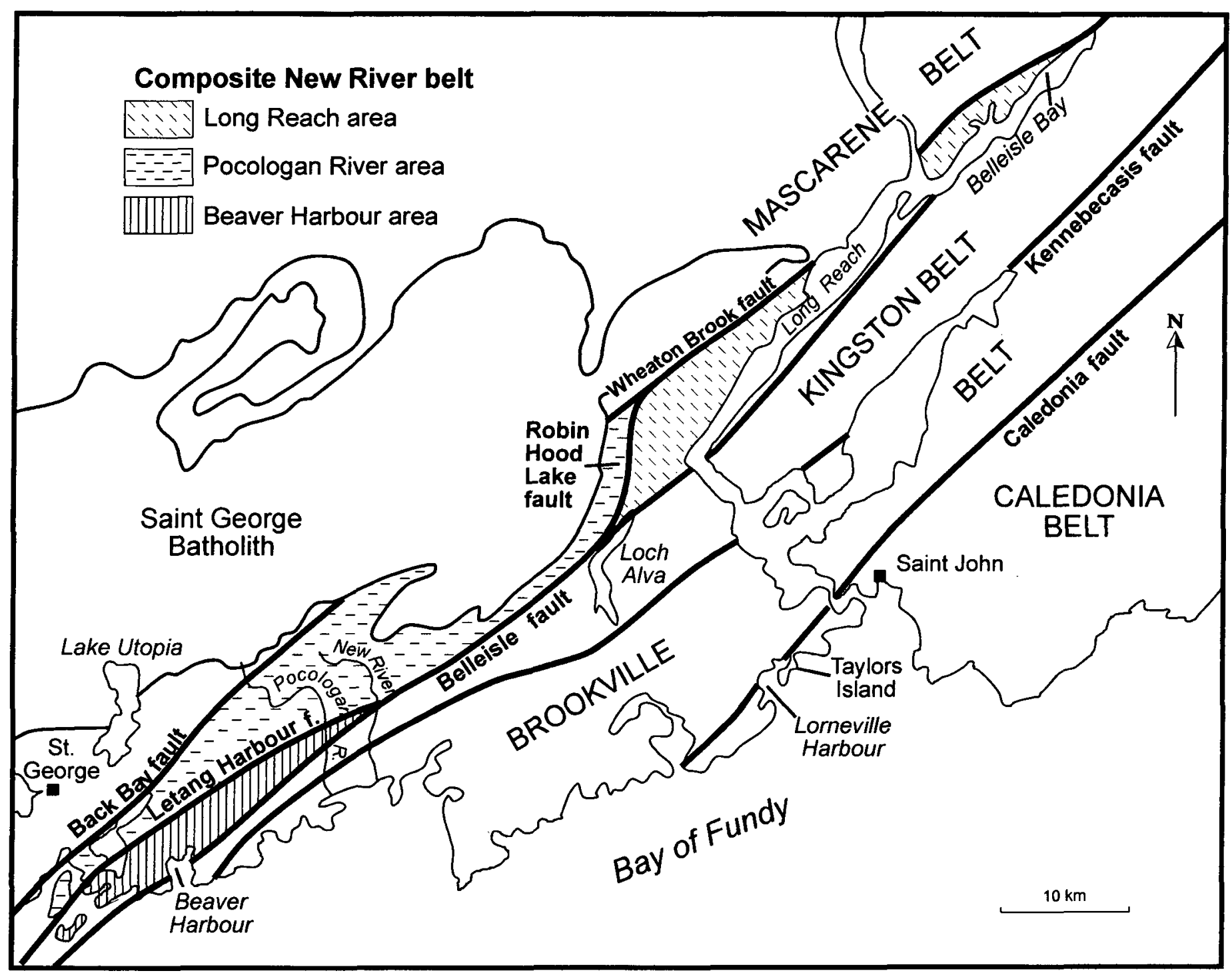

Fig. 2. Location of the composite New River belt and map areas referred to in text.

extensive faulting has resulted in several different interpretations of the stratigraphy and age of lithological units (compare MacKenzie 1964; McCutcheon 1981; Currie 1987, 1988, 1992; Currie and McNicoll 1999).

\section{Middle Neoproterozoic units}

\section{Lingley suite}

The name Lingley suite is herein used for compositionally expanded Neoproterozoic granitoid rocks that are approximately equivalent in extent to the Lingley Pluton of Currie (1987). The Lingley suite underlies much of the area northwest of the Belleisle fault from the north end of Loch Alva to Browns Flat (Fig. 3), but also occurs as small faulted units of tectonized granitoid rocks as far east as Belleisle Bay. The plutonic rocks comprise a heterogeneous group of related intrusions consisting mainly of red leucogranite, hornblende granodiorite, and tonalite (Currie 1987). The Lingley suite is strongly sheared and tectonically interleaved with younger volcanic and sedimentary rocks, particularly in the area between Robin Hood Lake and Highway 7 (Fig. 3).

Felsic rocks in the suite are mainly red to cream, fine- to medium-grained equigranular to porphyritic granite and tan and yellowish-green quartz porphyry. The granites are commonly highly fractured and limonite stained. They locally contain abundant small rounded quartz phenocrysts. The intermediate rocks are mainly medium-grained, grey hornblende granodiorite and tonalite but also include a significant amount of mafic dykes. Lingley granitoid rocks are commonly, but not everywhere, strongly foliated and have a cataclastic fabric within a zone of parallel north-northeasttrending shear zones in the Robin Hood Lake - Nerepis area.

Although Currie (1997) and Currie and McNicoll (1999) separated the granitoid rocks into the Lingley and Brittain Creek plutons, comprising red leucogranite and hornblende granodiorite to tonalite, respectively, I found both phases to be intimately associated at numerous localities. However, where possible, I divided them into either granitic or granodioritic phases. U-Pb zircon ages for the Lingley $(629 \pm 0.9 \mathrm{Ma})$ and Brittain Creek (625 $\pm 1 \mathrm{Ma}$ ) plutons (Currie and McNicoll 


\section{Cambrian}

Saint John Group

?rey sandstone, siltstone and shale

Neoproterozoic - Carboniferous?

Browns Flat Formation

Шग Mafic volcanic rocks, red sandstone and siltstone

Neoproterozoic - Early Cambrian

Beulah Camp Formation

MIJW Felsic and minor mafic pyroclastic rocks, red sandstone and siltstone

\section{Neoproterozoic}

\section{Lobster Brook Formation}

$\Delta_{\Delta} \Delta$ ca $554 \mathrm{Ma}$ felsic tuff and porphyry

Lingley suite

${ }^{x} x^{x} x^{x}$ ca. 625 Ma granitoid rocks
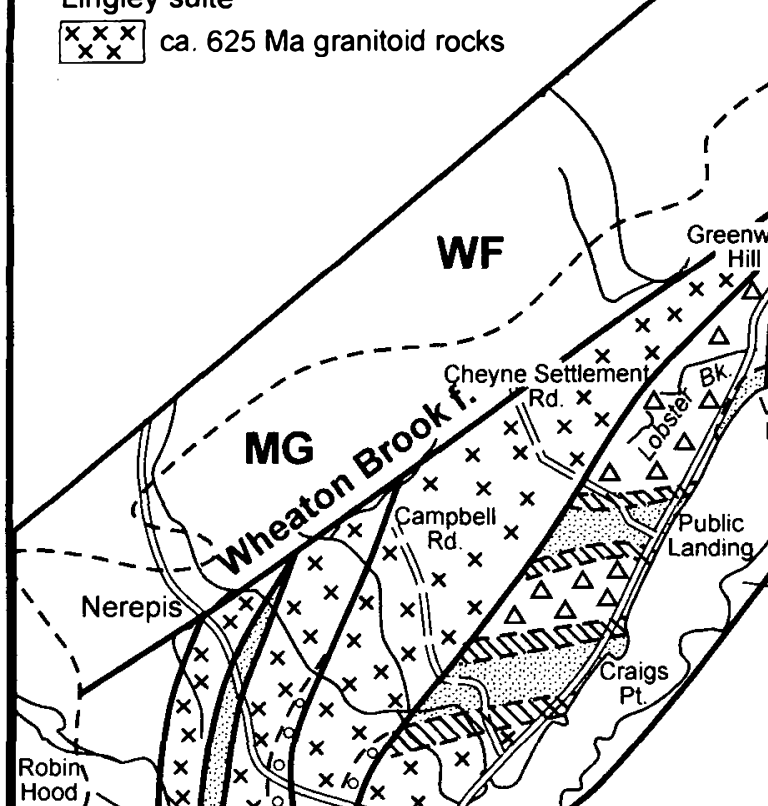

Hood

Lake

$S G$
1
1
1

SG!

$i_{1}^{1} \int^{x}$

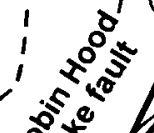

एi

KG

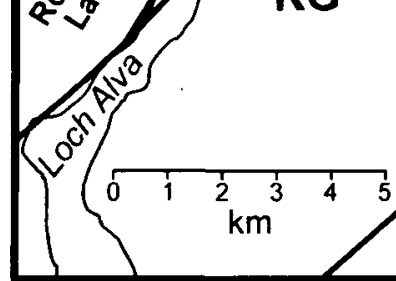
$f_{M G}$
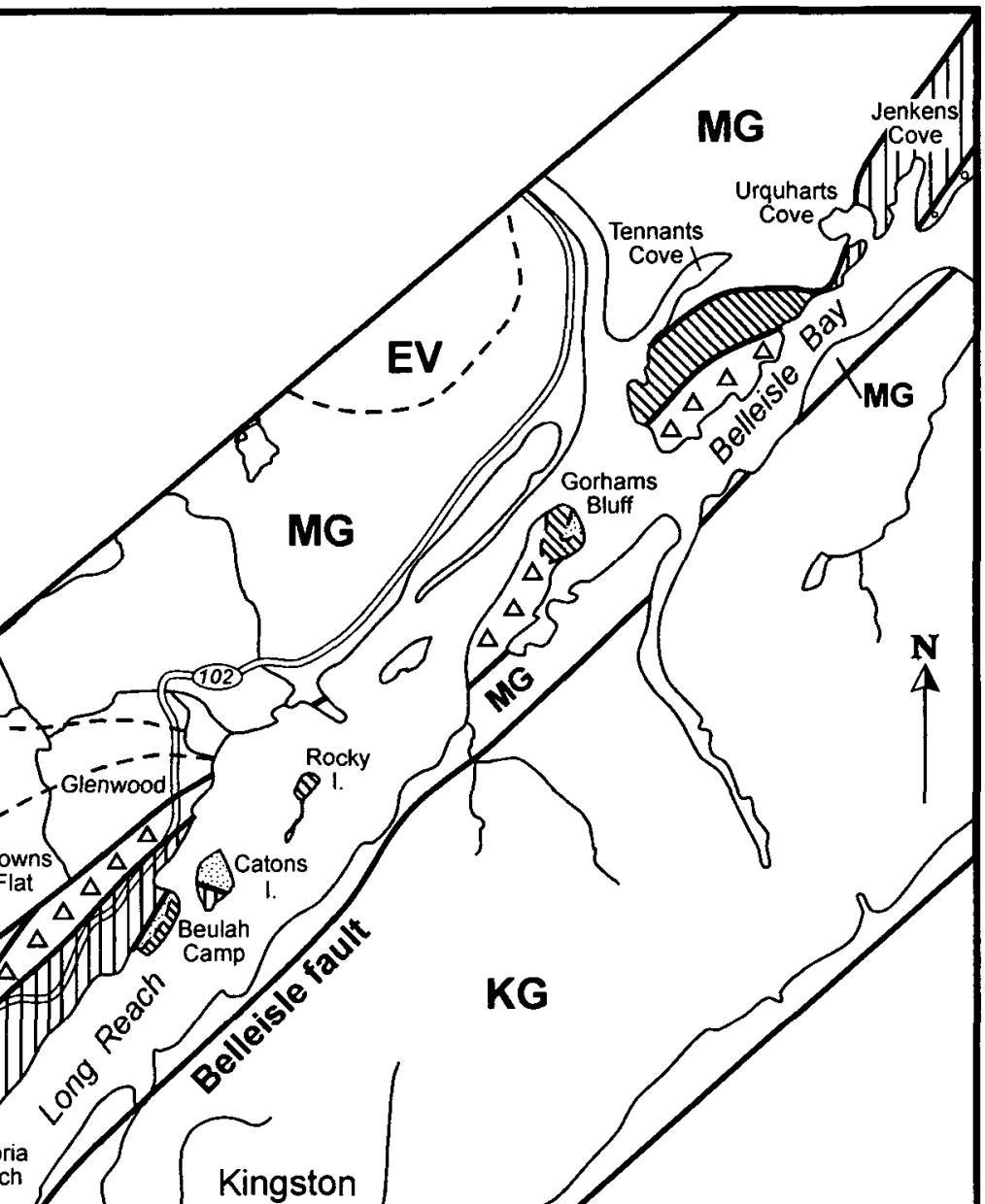

MG

Urquharts

15

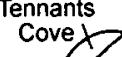

$\mathrm{E}$

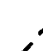

$\int($
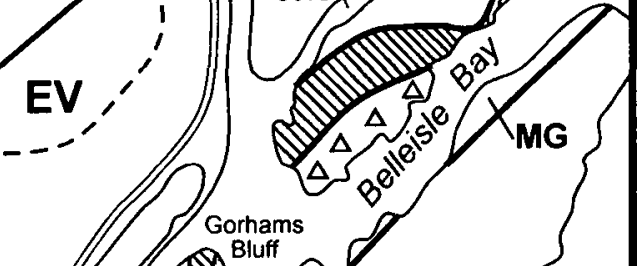

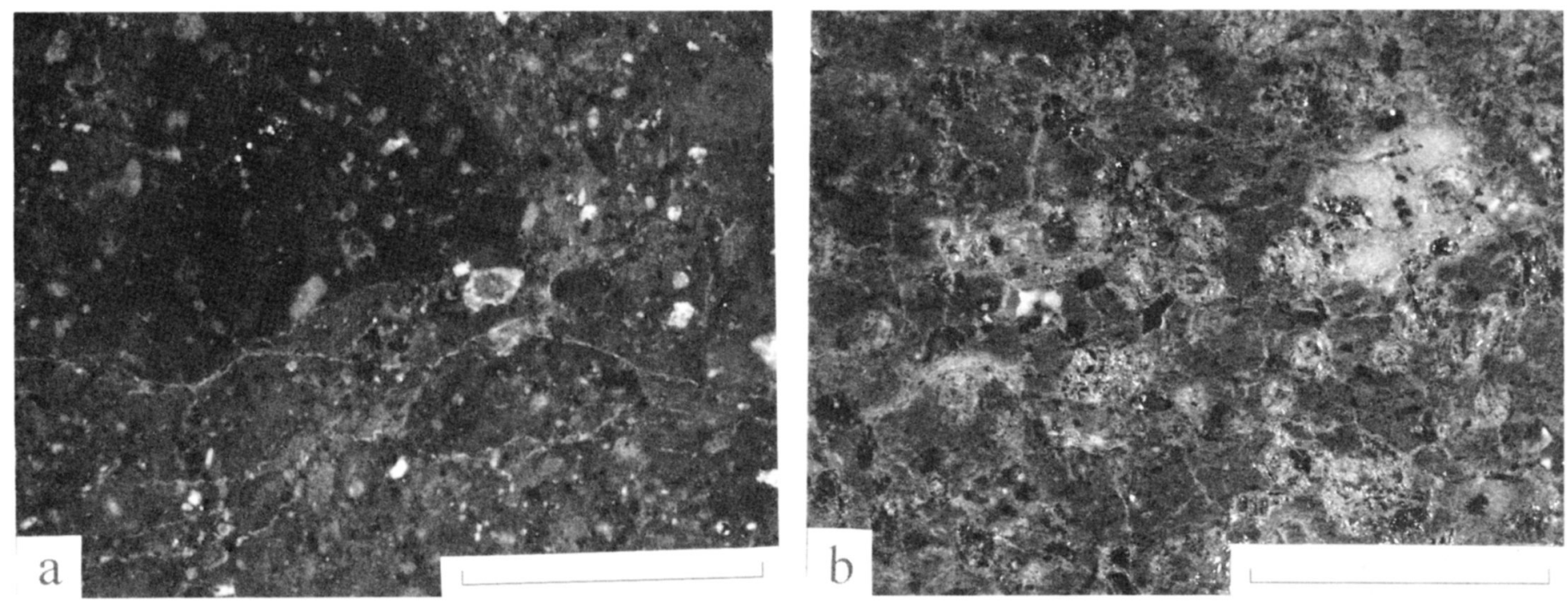

Fig. 4. Cut slabs of the Lobster Brook Formation. Bar scale $=1 \mathrm{~cm}$. a) Felsic lithic-crystal tuff with large volcanic fragment in upper left corner. b) Felsic lithic-vitric tuff.

1999) indicate that the Lingley suite is not coeval with ca. 555 Ma granitoid rocks in the Pocologan River area, as previously thought (Currie and Hunt 1991; Johnson and McLeod 1996).

\section{Late Neoproterozoic and younger (?) units}

\section{Lobster Brook Formation}

The Lobster Brook Formation is exposed west of the Saint John River from Craigs Point to Glenwood and on the south end of Rocky Island. It is equally well exposed in the Belleisle Bay area on the west and east shores of Gorhams Bluff, the peninsula east of Tennants Cove and in the vicinity of Urquharts Cove. The contact between the Lobster Brook Formation and granitoid rocks of the Lingley suite is not exposed but the linear nature of the contact suggests that it is a fault.

The Lobster Brook Formation comprises red to maroon and less commonly tan rhyolite porphyry, flow-banded ash tuff, felsic lithic-crystal tuff and minor microgranite porphyry. The subvolcanic rhyolite porphyry has a red, aphanitic matrix and typically contains small rounded quartz phenocrysts and feldspar laths. It commonly displays well-developed flow banding that is more prevalent in the area from Public Landing to Browns Flat than to the southwest. Vuggy textures are common in the porphyry due to abundant miarolitic cavities that impart a frothy appearance to the weathered surface. The cavities are up to $4 \mathrm{~cm}$ (diameter) but are generally smaller, less than $5 \mathrm{~mm}$. Distinctive, light green. colloform, subcircular, angular and tear drop shaped "fragments" are very common also. They may represent late stage in-filling of pore spaces between crystals. Although textural features typical of very high level intrusive rocks are present in some outcrops, unmistakable fragmental extrusive textures were observed in others. Previous workers considered the Lobster Brook Formation to be entirely intrusive (e.g. MacKenzie 1964: McCutcheon 1981; Greenough et al. 1985; McCutcheon and
Ruitenberg 1987). A number of the "intrusive rhyolites" contain flattened pumaceous fragments and red to purple aphyric to quartz-phyric felsic volcanic clasts with welldefined, sharp boundaries (Fig. 4a, b).

A spectacular volcanic conglomerate in the Lobster Brook Formation is exposed in a new outcrop on the Pit Road, south of Lobster Brook (Fig. 5). Well-rounded, red and green porphyry boulders, up to $0.5 \mathrm{~m}$ diameter, occur in a green quartz porphyry matrix. Red porphyry boulders are in places chilled against greenish boulders. Other porphyry boulders have amoeboid protuberances and veins that penetrate the matrix. These mixing textures and the roundness of the boulders suggest that the material was fairly hot when it moved down slope. The rock is interpreted to be a volcanic debris flow, possibly related to the development of a rhyolite dome.

A U-Pb (zircon) date of $554 \pm 6 \mathrm{Ma}$ from rhyolitic, crystal-rich ash tuff in the Lobster Brook Formation at Gorhams Bluff demonstrates that the formation is Late Neoproterozoic age (Barr et al. 1999). Complex faulting in the area makes it impossible to say for certain that the dated tuff is equivalent to the main body of the Lobster Brook Formation on the west side of the Long Reach, but in the author's opinion, it is the most reasonable interpretation. Currie and McNicoll (1999) suggested that the Lobster Brook porphyries might be equivalent in age to the ca. 630-625 Ma Lingley suite based on lithological similarities. Although the porphyries are superficially similar, distinctions can be made. Intrusive porphyry in the Lobster Brook Formation, unlike the Lingley, almost everywhere exhibits subvolcanic textures such as miarolitic cavities and flow banding and is transitional to extrusive felsic lithic tuffs and flow-banded ash-flow tuffs. Although these distinctions could be explained by exposure of differing intrusive levels within the same pluton, available lithological and radiometric evidence indicates that the Lobster Brook Formation is not time-equivalent with the Lingley suite. The Lobster Brook Formation contains rocks 


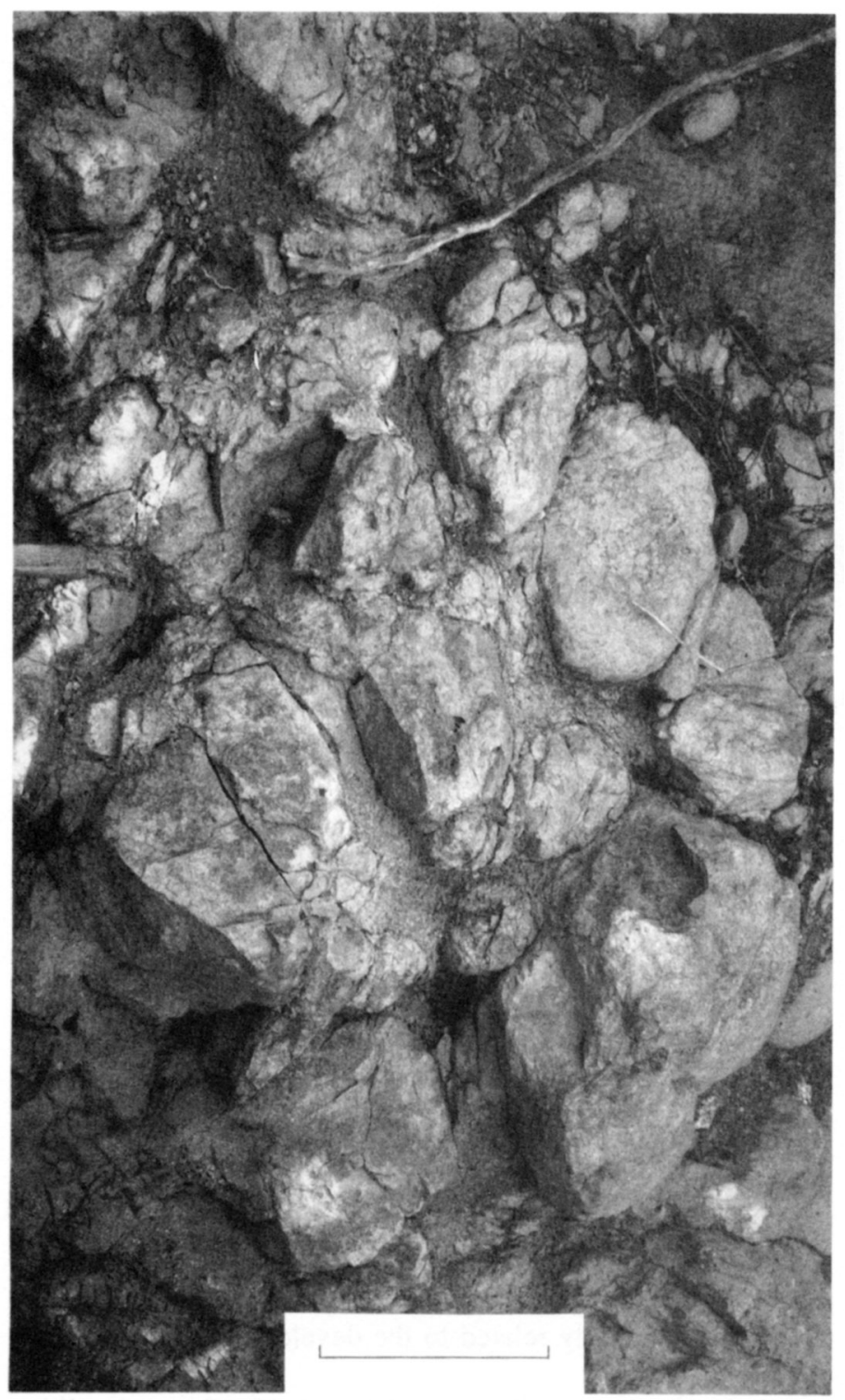

Fig. 5. Field photograph of Lobster Brook Formation volcanic conglomerate. Bar scale $=15 \mathrm{~cm}$.

included in Unit $\operatorname{Esjp}_{2}$ of McCutcheon (1981), Unit $\complement_{6}$ of Greenough et al. (1985) and the "Woodmans Point Volcanics" (Currie 1997).

\section{Browns Flat Formation}

Mafic volcanic rocks and red beds assigned to the Browns Flat Formation are exposed on the shore and on adjacent hills west of the Long Reach in the Browns Flat and Greenwich Hill areas. On the shore of Belleisle Bay these rocks crop out in the vicinity of Urquharts and Jenkins coves (Johnson 2000). Fault-bounded units of basalt and red beds on Highway 7 south of Nerepis are also included in the formation. On the west side of the Long Reach from Greenwich Hill to Browns Flat, younging directions establish that the shallow to moderate east-southeast dipping section is upright, except near major faults where bedding is locally overturned. The Browns Flat Formation is comprised of three members, a lower unit of mafic volcanic rocks and red to grey sandstone and siltstone (Gorham Road Member), a medial unit of mainly red sandstone and conglomeratic sandstone (Greenwich Hill Member) and an upper unit of mafic volcanic rocks and red to grey siltstone (Victoria Beach Member). The formational thickness is estimated at over $500 \mathrm{~m}$ based on a NW-SE section constructed across the Greenwich Hill area.

The Gorham Road Member consists of mafic flows, tuffs, and agglomerate interbedded with red brown to maroon and rare brick red and grey green, shale, siltstone, and very finegrained sandstone and medium-grained to pebbly, lithic, and arkosic sandstone. Mafic volcanic rocks near the base are exposed on the Gorham Road, on Highway 102, and on the railroad tracks west of Catons Island. Mafic volcanic rocks near the base of the member consist chiefly of grey green basalt commonly containing very small $(<2 \mathrm{~mm})$ vesicles filled with hematite, carbonate, or chlorite. Hematitized mafic lithic tuffs, locally containing exotic granite fragments, are also present. Cherty hematite, as veins and vesicle-fillings, is characteristic of the mafic rocks. On an unnamed brook west of Public Landing, basalt with a cherty hematite base is underlain by red sandstone, maroon and green siltstone and thin- to medium-bedded, yellowish-tan ash beds and very thinly laminated dark grey mudstone with chaotic bedding. Graded bedding and planar cross-bedding in the ash beds indicate the section is upright and the basalt lies at the top. Similar thin, volcanic ash beds, interbedded with red and maroon siltstone and sandstone, were observed in an isolated exposure on an unnamed brook opposite Craigs Point and these rocks are also tentatively assigned to this member. The Gorham Road Member is approximately equivalent to Unit $€_{1}$ of Greenough et al. (1985).

On the railroad track south of Glenwood, thinly laminated red brown siltstone and mudstone with interbeds of light grey to pink very fine-grained quartzose sandstone conformably overlie basalt of the Gorham Road Member. At the contact with the basalt, the red beds are mottled; however, it is not considered to be significant as similar variegation was observed in the red beds up-section of the contact. Graded bedding demonstrates that the section is overturned and the red beds at this locality overlie the basalt. These red clastic rocks are assigned to the overlying Greenwich Hill Member.

The Greenwich Hill Member consists of red brown to maroon, and rare brick red and grey green, thinly laminated siltstone to very fine-grained sandstone and greyish-pink, fineto medium-grained and pebbly, lithic sandstone, and pebble to granule conglomeratic sandstone. The best exposures are found on Greenwich Hill and Highway 102 south of Browns Flat. The sandstone is thin- to thick-bedded, slightly to moderately micaceous and commonly exhibits grading. Red shale rip-up clasts are common at the bases of the pebbly conglomeritic sandstone layers.

On Catons Island, similar fine-grained, maroon and grey green, micaceous sandstone and siltstone, maroon pebbly sandstone and conglomerate are in faulted contact with Cambrian rocks of the Saint John Group. The conglomerate contains large, sub-rounded pebbles of red quartz porphyritic granite and maroon sub-volcanic porphyry, quartzite, red sandstone, grey quartz-phyric rhyolite and maroon quartz- 
veined quartz pebbles. Pebbles of maroon sub-volcanic porphyry of the Lobster Brook Formation and red quartzporphyritic granite tentatively assigned to the Lingley suite indicate that this conglomerate is younger than Late Neoproterozoic. These lithologies are similar to those in the Greenwich Hill Member to which they are tentatively assigned, following Greenough et al. (1985). This assignment is somewhat troubling because no mafic volcanic rocks occur on Catons Island and coarse polymictic conglomerate does not occur in the Browns Flat Formation on the mainland.

The Victoria Beach Member is exposed only on the abandoned railroad tracks near Victoria Beach and on the hills to the west. At this locality a $30-40 \mathrm{~m}$ thick, columnar-jointed mafic flow or sill overlies red brown, maroon and green-grey siltstone and sandstone. Fine-grained, grey, quartzose sandstone beds ( $1-2 \mathrm{~cm}$ thick) with sharp bases and wavy tops young to the southeast. Small, hematite-filled vesicles and cherty hematite/epidote veining are common in these rocks. The most striking feature of this member is columnar joints that are oriented perpendicular to the underlying red beds of the Greenwich Hill Member, signifying a concordant relationship between the two. McCutcheon and Ruitenberg (1987) presented evidence both for and against a flow origin for this mafic unit, but the textural homogeneity is more characteristic of a sill. The Greenwich Hill Member is equivalent to Unit $\epsilon_{3}$ of Greenough et al. (1985).

The age of the Browns Flat Formation is still poorly constrained. Lithological similarities between the Browns Flat and Beulah Camp formations, such as the presence of maroon to red lithic sandstone, siltstone, and tuffaceous sandstone in both formations was the basis for including the Browns Flat Formation in the same sequence as the Lobster Brook and Beulah Camp formations in the past, albeit of different age and stratigraphic order (compare MacKenzie 1964; McCutcheon 1981; Currie 1987, 1988, 1992; Currie and McNicoll 1999). McCutcheon (1981) and Greenough et al. (1985) considered all three formations to be Early Cambrian based on stratigraphic position, inferred relationships, and the similarity of the red beds to those in the basal Saint John Group (Ratcliffe Brook Formation). Currie (1988, 1992, and 1997) argued that the entire sequence is probably "Eocambrian" (Latest Neoproterozoic) and correlative with the Lorneville Beds near Saint John.

An increasing body of evidence suggests a DevonoCarboniferous age for the Browns Flat Formation. During this study, spores were collected from a grey mudstone horizon within the "Sagwa red beds" near Highway 7, which McCutcheon and Ruitenberg (1987) considered to be equivalent to the Browns Flat Formation in the Greenwich Hill area. The spores indicate a Devonian or younger age for the Sagwa beds (G. Dolby, written communication, 1998), although he cautioned that the results must remain tentative due to the high carbonization of the organic residue. Although the Sagwa and Browns Flat sandstones are petrographically similar according to McCutcheon and Ruitenberg (1987), the former unit is dominated by granite-clast conglomerate that is not found in the Browns Flat Formation; therefore, a definitive correlation cannot be made.
It is noteworthy that spores were recently obtained from the correlative(?) Lorneville Beds on Taylors Island, which also lack granite-clast conglomerate. A preliminary Devonian or Carboniferous spore age for the Lorneville Beds ( $R$. Fensome, personal communication, 2001) confirms the young age proposed for these rocks by Alcock (1938), and later Rast et al. (1978) and Barr and White (1999). The lack of deformation and alteration in the Lorneville Beds and Browns Flat Formation as compared to the Cambrian Saint John Group was addressed by Currie (1992, p. 42), although he attributed the differences to the buttressing effect of the volcanic rocks in the former.

\section{Beulah Camp Formation}

The name Beulah Camp Formation is given to the excellent exposure of red pyroclastic and epiclastic rocks found along the shore of the Long Reach at Beulah Camp, on the northern end of Rocky Island, and at the northern end of Gorhams Bluff (Fig. 3). The formation is also well exposed on the east side of Tennants Cove and on the Belleisle Shore Road west of Belleisle Bay. Felsic tuff, maroon volcanogenic sandstone and green-grey siltstone and sandstone on Campbell Road (Fig. 3), assigned to the Ratcliffe Brook Formation of the Saint John Group by Tanoli (1987), are also tentatively included in the Beulah Camp Formation.

The Beulah Camp Formation comprises reddish-maroon, coarse- to fine-grained felsic and minor mafic pyroclastic rocks, chiefly felsic lithic-crystal tuff. The tuffs have a red hematite-rich matrix and contain abundant small euhedral feldspar crystals and small $(<1 \mathrm{~mm}$ to $3 \mathrm{~cm})$, flattened, angular felsic volcanic clasts and vitric shards. Rare accidental granite clasts were also observed in the tuffs. Basaltic fragments are abundant in the coarse lithic tuff at Gorhams Bluff where they underlie an amygdaloidal basalt flow near the top of the section. The pyroclastic rocks are interbedded with raspberry red to maroon and red brown, thin- bedded siltstone and tuffaceous siltstone and sandstone, brick red shale and minor greyish-pink fine- to medium-grained lithic sandstone.

Neither the base nor the top of the Beulah Camp Formation is exposed; however, the formation consistently occupies the stratigraphic position immediately below the late Early Cambrian Hanford Brook Formation in the map area. At Gorhams Bluff (Fig. 3) parallel bedding attitudes and younging directions indicate that the latter directly overlies the Beulah Camp Formation. However, the abrupt change in lithology suggests a disconformable rather than conformable relationship. Hence, an Early Cambrian or older age is indicated for the Beulah Camp Formation. The formation is equivalent to Unit $\epsilon_{4}$ of Greenough et al. (1985) and the raspberry pyroclastics of Hayes and Howell (1937, p. 103).

Greenough et al. (1985) placed the Beulah Camp Formation above the mafic volcanic and red beds of the Browns Flat Formation. The stratigraphic order suggested by these authors is apparently based on continuity between the east-younging Browns Flat Formation and the rocks exposed on the shore at Beulah Camp, the only locality where the two formations are adjacent. In this section, bedding in the Beulah Camp Formation dips both west and east; however, graded bedding suggests that the section youngs to the west. Although 
a synclinal fold can be invoked to explain the dip reversals, a faulted contact between the pyroclastic rocks on the shore and the east-younging Browns Flat Formation inland is suggested for the following reasons. A small outcrop of Hanford Brook Formation sandstone, immediately west of the shore, indicates that the raspberry pyroclastic rocks are overlain to the west by Saint John Group strata. Opposite-facing Browns Flat Formation sandstone directly along strike of these rocks leaves no room for a fold. These relationships alone do not rule out the possibility that the Browns Flat Formation lies stratigraphically below the Beulah Camp Formation. However, stratigraphic continuity between the Browns Flat and Beulah Camp formations cannot be established in this, or any other, section in the map area, although sandstone in both formations appears to be lithologically similar.

\section{Cambrian units}

The presence of Cambrian strata in the Long Reach area has been known at least since the time of Matthew (1890, 1891). Since then, detailed work by several workers indicated that these rocks can be correlated with the Saint John Group in the Saint John area (Yoon 1970; Tanoli and Pickerill 1988; Landing and Westrop 1996; McCutcheon and Ruitenberg 1987). I concur, with the exception of dark grey shale and highly sheared basalt at Glenwood (Fig. 3) that were included in the Saint John Group by McCutcheon and Ruitenberg (1987) and Greenough et al. (1985). Fossils were discovered in the grey shale and calcareous nodules in the shale at Glenwood, indicating that these rocks are Silurian age (M.J. McLeod, unpublished data). The faunal assemblage of thelodonts and the crustacean Ceratiocaris pusilla is almost identical to that reported from calcareous nodules on Cunningham Brook in the upper Jones Creek Formation near Nerepis (Copeland 1889; Turner 1986). Consequently, the basalt and shale sequence at Glenwood has been removed from the Saint John Group.

\section{Saint John Group}

Formational nomenclature for the Saint John Group employed herein follows Tanoli (1987) and Tanoli and Pickerill (1988), however, boundary revisions and significant disconformities as outlined in Landing (1996) and Landing and Westrop (1998) are taken into consideration (Fig. 6). In addition to a new fossil locality discovered on the Cheyne Settlement Road during this study (see below), Cambrian fossils were previously reported from Public Landing and Victoria Beach on the mainland (Yoon 1970) and on Catons Island (Matthew 1891; Landing and Westrop 1996). Saint John Group strata are also found in isolated fault blocks on Highway 7 south of Nerepis and near Westfield (Fig. 3). Catons Island was not remapped during this study and the reader is referred to Landing and Westrop (1996 and references within) for a detailed description of the Cambrian rocks in this area.

On the mainland, rocks assigned to the Saint John Group are divided into four lithological units, all of which are tentatively assigned to the Early Cambrian Hanford Brook Formation. Landing and Westrop $(1996,1998)$ and Westrop

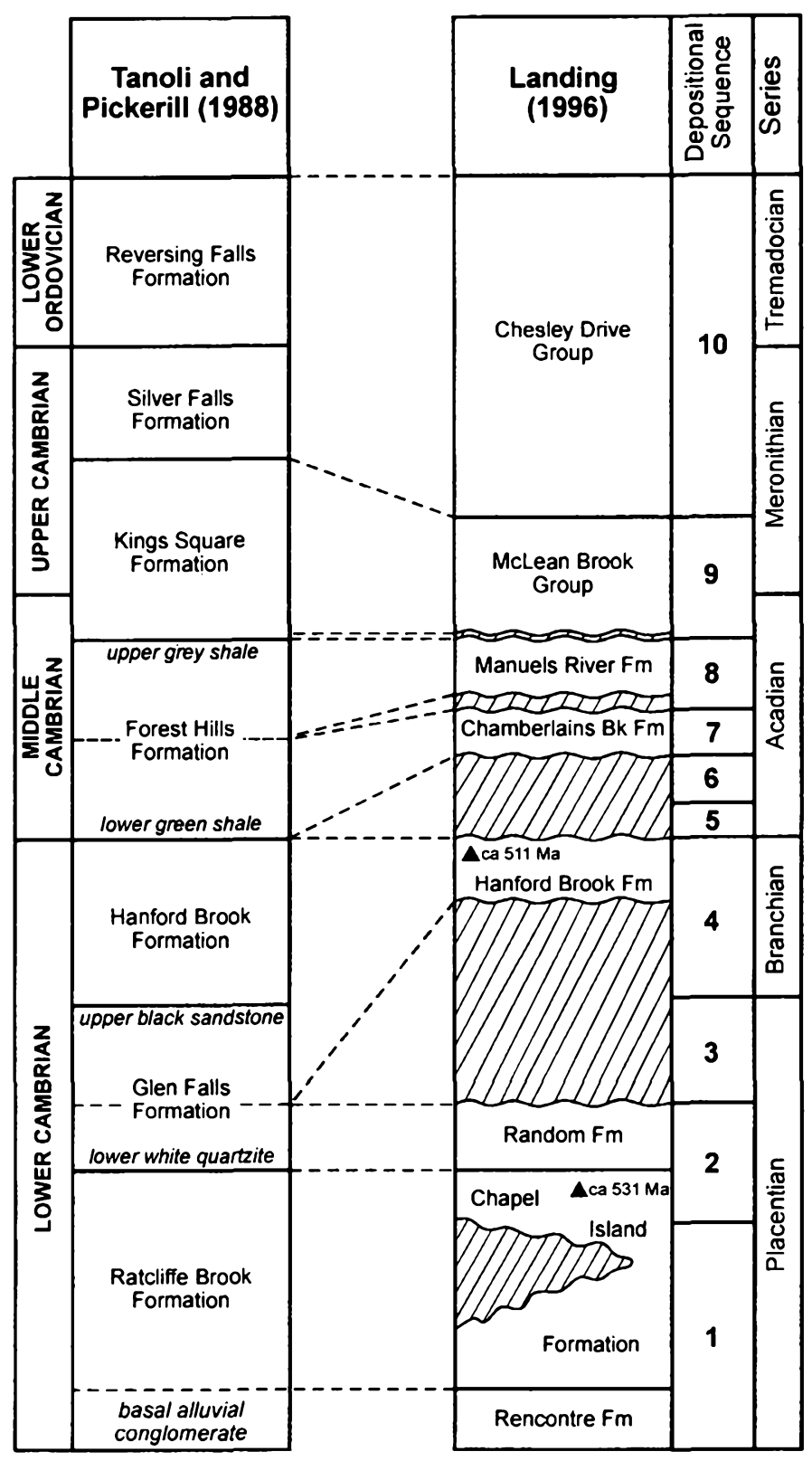

Fig. 6. Revised formational boundaries of the Cambrian - Lower Ordovician Saint John Group with respect to depositional sequences of Landing (1996) and Landing and Westrop (1998). Triangles represent volcanic ash-beds with radiometric age control. Saint John Group nomenclature in text after Tanoli and Pickerill (1988).

and Landing (2000) divided the Hanford Brook Formation in the Saint John area into three members. The lowermost St. Martins Member comprises grey, fine-grained, commonly phosphatic sandstone containing abundant bradoriids and linguloid and acrotretid brachiopods. The overlying Somerset Street Member comprises alternations of medium to dark grey siliciclastic mudstone and fine-grained micaceous quartz arenite containing a low diversity faunal assemblage comprising bradoriids, inarticulate brachiopods and trilobites (Westrop and Landing 2000). The overlying Long Island Member is dominated by grey, fine-grained sandstone with a bradoriid-inarticulate brachiopod assemblage and local 
trilobites (Westrop and Landing 2000). Massive conglomeratic sandstone is locally preserved at the base of the Long Island Member.

The first lithological unit, assigned to the Long Island Member of the Hanford Brook Formation, comprises massive, grey to greenish-grey, very fine- to fine-grained. micaceous sandstone. This unit is exposed on Route 102, on the railroad tracks $0.9 \mathrm{~km}$ north of the Public Landing wharf and on the railroad southwest of Victoria Beach (Fig. 3). Yoon (1970) previously correlated these rocks with the Hanford Brook Formation based on his discovery of Early Cambrian trilobites in these rocks north of Public Landing. The presence of trilobites in this unit demonstrates that it cannot be correlative with the St. Martins Member because the lowest occurrence of trilobites in the Hanford Brook Formation is in the Somerset Street Member (Landing and Westrop 1996, 1998; Westrop and Landing 2000). Lithologically, the trilobite-bearing sandstones at Public Landing more closely resemble the sandstone-dominated Long Island Member than the siliciclastic mudstone of the Somerset Street Member, hence their assignment to this member.

The second lithological unit comprises grey, fine- to very fine-grained, micaceous sandstone similar to the Long Island Member, with the addition of thin (less than $2 \mathrm{~cm}$ ) beds of dark grey mudstone. The sandstone is commonly burrow churned and contains abundant phosphate nodules and pebbles up to $\mathrm{I} \mathrm{cm}$ in diameter (Fig. 7). Thin-bedded, medium grey to green siltstone and grey shale is locally interbedded with the sandstone. This unit is best exposed on the Cheyne Settlement Road approximately $1.1 \mathrm{~km}$ north of the Public Landing wharf, at Gorhams Bluff, and on a small brook in Beulah Camp.

Well-preserved inarticulate brachiopods were discovered in this unit on the Cheyne Settlement Road during this study. The most abundant fauna are small, $(2-3 \mathrm{~mm})$. black phosphatic shells that, in the author's opinion, most resemble the acrotretid brachiopod Linnarsonnia misera from the upper part of the (Middle Cambrian) Forest Hills Formation (Matthew 1886, p. 35). The latter is reported to consist of either massive mudstone (Tanoli and Pickerill 1988) or dark grey to black shale with calcareous nodules and thin ash beds
(Landing and Westrop 1998), but the phosphatic, brachiopodbearing sandstone is more typical of the Hanford Brook Formation. Therefore, pending further assessment of the brachiopods, the exact stratigraphic position of these rocks must remain tentative.

The brachiopod-bearing sandstone immediately overlies red tuffaceous sandstone of the Beulah Camp Formation. The contact is not exposed, but bedding attitudes are parallel, suggesting a disconformable relationship with the Late Neoproterozoic-Early Cambrian Beulah Camp Formation. At Gorhams Bluff and Beulah Camp these rocks occupy the same stratigraphic position with respect to the Beulah Camp Formation, suggesting that the Hanford Brook Formation composes the oldest part of the Saint John Group on the mainland.

The third lithological unit comprises thinly laminated, medium grey siltstone and mudstone with lenses and very thin- to medium-beds $(0.5-10 \mathrm{~cm})$ of white quartz arenite. These rocks are exposed in the woods east and west of the Cheyne Settlement Road. Complications due to folding, poor exposure, and scant younging directions make it difficult to say for certain, but it appears that this unit regionally overlies the brachiopod-bearing sandstone. If the latter is correlative with the St. Martins Member at the base of the Hanford Brook Formation, then this mudstone-dominated unit could be assigned to the overlying Somerset Street Member.

The fourth lithological unit consists of fine-grained, micaceous quartz-rich arenite, light grey to white, medium- to coarse-grained quartz-rich arenite containing quartz granules to small pebbles and polymictic pebble conglomerate. This unit is correlated with coarse-grained quartz arenite and conglomeratic sandstone at the revised base of the Long Island Member (Landing and Westrop 1996, 1998, p. 80-81). This unit is exposed on the Cheyne Settlement Road approximately $600 \mathrm{~m}$ north of the Public Landing wharf and on Campbell Road. At the latter locality the pebbly sandstone gradationally overlies grey polymictic conglomerate containing well rounded to angular clasts of quartz, mafic and felsic volcanic rocks, granite, maroon tuff, and green, grey and maroon siltstone. The conglomerate and pebbly sandstone are overlain by greenish-grey, thin-bedded $(2-10 \mathrm{~cm})$, fine-grained

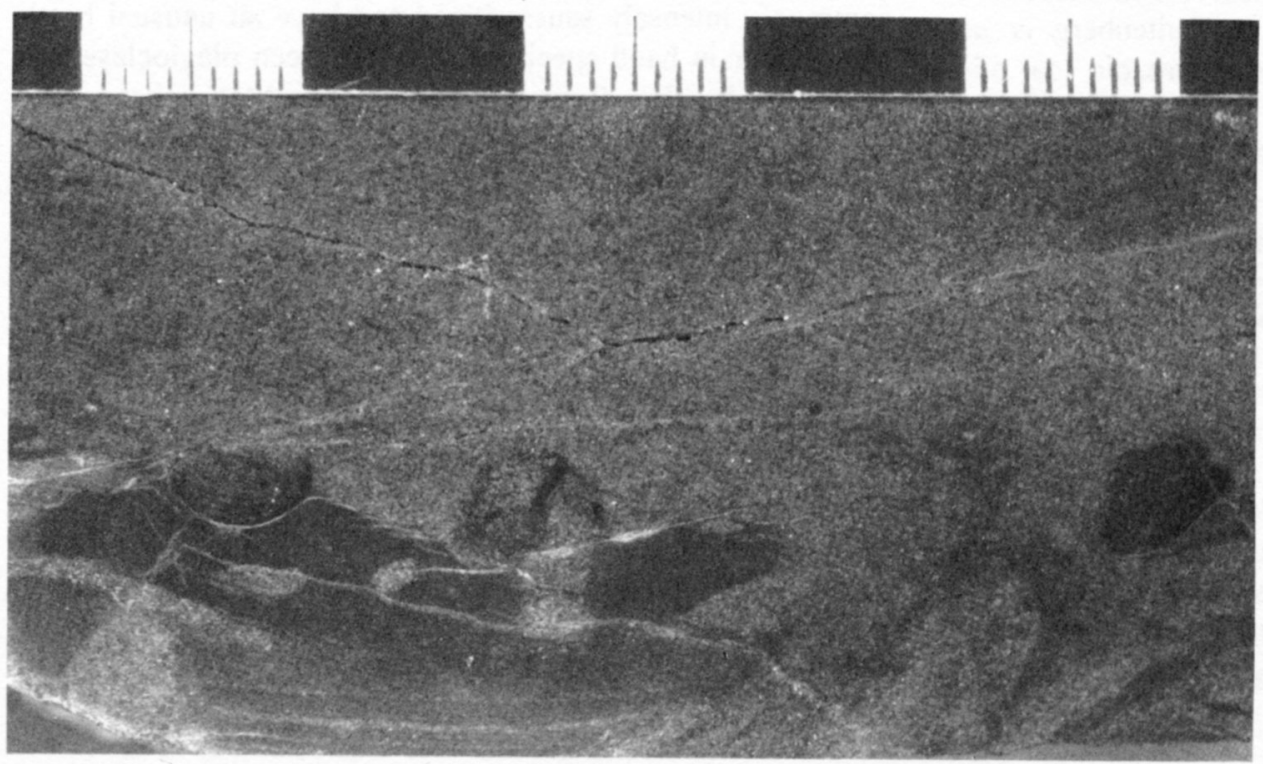

Fig. 7. Fine-grained. burrow-churned. sandstone with phosphatic nodules (Hanford Brook Formation). Bar scale in centimetres. 
sandstone interbedded with $2-6 \mathrm{~cm}$ beds of micaceous quartzrich arenite locally containing quartz granules, medium greenish-grey to olive shale, and thin-bedded siltstone. Lithologically similar rocks overlie conglomeratic sandstone containing extra-basinal clasts (up to $2 \mathrm{~cm}$ ) of vein quartz and rhyolite at the base of the Long Island Member on Hanford Brook West (Landing and Westrop 1996, Fig. 2; 1998, p. 80 81). The Campbell Road and Long Island Member conglomerates are different, but both record a stratigraphic break involving erosion of Neoproterozoic basement rocks. For these reasons a correlation with the Long Island Member is also proposed for these rocks.

\section{Correlation}

Neoproterozoic and Cambrian rocks in the Long Reach belt can be correlated with relative ease to the classic Avalon zone succession, typical of the Caledonia belt in the Saint John area (e.g. Barr and White 1996a, 1996b, 1999; Barr et al. 1994). As illustrated on Fig. 6, formations of the Saint John Group can be correlated into depositional sequences that are consistent throughout the Cambrian over-step sequence of Avalon (Landing 1996). Lithofacies, biofacies, and sequence boundaries within the Cambrian rocks in the Long Reach area can be precisely correlated with those in the Saint John Group in the Saint John area (Tanoli and Pickerill 1988; Landing and Westrop 1996).

Other comparisons can be made; Neoproterozoic igneous activity in the Caledonia belt can be divided into an earlier (ca. 625-600 Ma) subduction-related event and a later (ca. 560$550 \mathrm{Ma}$ ) episode of extensional magmatism (Bevier and Barr 1990; Barr et al. 1994; Barr and White 1999). The earliest event is preserved in the Broad River Group, which contains metasedimentary and calc-alkaline metavolcanic and associated plutonic rocks produced in a magmatic arc setting. Although volcanic and sedimentary rocks correlative with the Broad River Group have not been identified in the Long Reach belt, the compositionally-expanded plutonic rocks of the ca. 629-625 Ma Lingley suite are comparable in age and composition to the older plutonic rocks in the Caledonia belt. Late Neoproterozoic bimodal magmatism in the Caledonia belt is represented by sedimentary, volcanic and associated plutonic rocks of the Coldbrook Group (Ruitenberg et al. 1979; Barr and White 1999). Late Neoproterozoic (ca. 554 Ma) felsic volcanic rocks of the Lobster Brook Formation and Late Neoproterozoic to (?) Earliest Cambrian mafic and felsic pyroclastic and epiclastic rocks of the Beulah Camp Formation are lithologically comparable to basaltic and rhyolitic volcanic and sedimentary rocks in the upper part of the Coldbrook Group. Like the Lobster Brook and Beulah Camp formations, rocks of the upper Coldbrook Group in the Caledonia belt are stratigraphically overlain by Cambrian to Early Ordovician marine sedimentary rocks of the Saint John Group (Barr and White 1999, p. 19).

Although distinctions can be made, particularly in the Neoproterozoic, the presence of Saint John Group as stratigraphic cover to Late Neoproterozoic volcanic and sedimentary rocks in the Long Reach area demonstrates it is comparable to the Caledonia belt, as suggested by Currie and
McNicoll (1999).

\section{Geology of the Pocologan River area}

The Pocologan River map area extends from the north end of Loch Alva to Letang Harbour (Fig. 8). For the purpose of this paper, the boundary with the Long Reach map area is drawn at the Robin Hood Lake fault, a major, north-trending fault zone extending from the northeastern end of Loch Alva to Robin Hood Lake (McCutcheon and Ruitenberg 1987). The main access is by Highway 1 and Route 780 in the southwestern part and Highway 7 in the northeastern part of the map area. Johnson and McLeod (1996) previously published the bedrock geology for the southwestern part of the Pocologan River map area. The results of more recent mapping near Loch Alva combined with previously published data are below.

\section{Late Neoproterozoic units}

Late Neoproterozoic plutonic rocks form the bulk of the exposures in the Pocologan River map area. They are divided into two intrusive suites referred to as the Ragged Falls suite and Rocky Lakes suite after Currie $(1987,1988)$. The Ragged Falls suite crops out in a northeast-trending belt extending from Letang Harbour to Lepreau River. These intrusive rocks are also well exposed on New River and on Pocologan River northeast of the town of St. George. The Rocky Lakes suite is best exposed on the hills surrounding Rocky Lakes on the northwest side of Loch Alva, extending from Seven Mile Lake in the southwest to Robin Hood Lake in the northeast. It underlies an area greater than $24 \mathrm{~km}^{2}$, most of which is accessible only on foot.

\section{Ragged Falls suite}

The Ragged Falls, Goose Lake, and Pull and Be Damned plutons of Currie (1987) comprise the Ragged Falls suite as described below. The suite contains medium- to coarsegrained syenogranite, monzogranite, tonalite, and gabbro (Currie 1987). The intrusive rocks are mylonitic and commonly contain shear bands. The plagioclase feldspars are commonly intensely sausseritized and have an unusual bottle green color in hand specimen. Similar green plagioclase was observed in the Rocky Lakes suite. McCutcheon and Ruitenberg (1987) attributed the greenish color to abundant $\mathrm{Fe}-\mathrm{Ti}$ oxide inclusions in the feldspars. The Ragged Falls and Pull and Be Damned complex are petrographically indistinguishable and differ only in that the latter contains numerous mafic dykes. The age of the Ragged Falls suite is constrained by two U-Pb zircon ages of $555 \pm 2 \mathrm{Ma}$ and $555 \pm$ $10 \mathrm{Ma}$ for granodiorite and granite, respectively (Currie and Hunt 1991; Johnson and McLeod 1996).

\section{Rocky Lakes suite}

The Rocky Lakes suite as herein defined comprises pink to greenish-grey, medium- to coarse-grained, porphyritic to equigranular granite and grey to green, medium- to coarsegrained, granodiorite, tonalite and quartz diorite cut by 


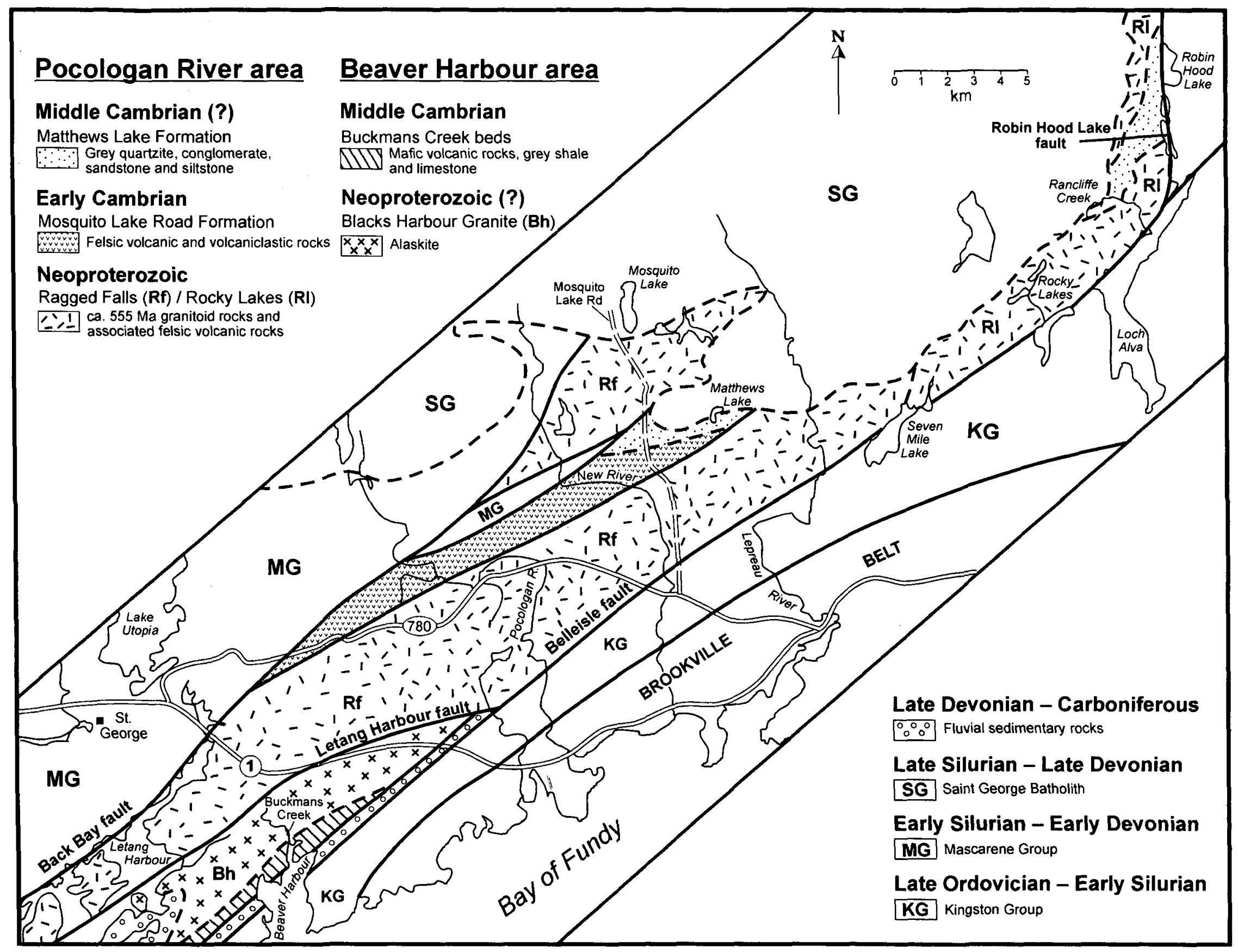

Fig. 8. Simplified geological map of the Pocologan River and Beaver Harbour areas (modified after Johnson and McLeod 1996), showing the distribution of major lithological units and geographic names referred to in text. 
numerous massive to amphibolitic mafic dykes. The more mafic phases are exposed in the southeastern part of the suite on the western shore of Loch Alva. Modal analyses indicate that intrusive rocks of the Rocky Lakes suite are compositionally expanded (McCutcheon and Ruitenberg 1987). Coeval relationships for the different phases are suggested by the gradational nature of the intrusive contacts. The intrusive rocks possess a moderate cleavage that intensifies to a strong, northeast-trending, steeply southeastdipping tectonic fabric toward the Belleisle fault (Fig. 8).

Porphyritic microgranite, fine-grained granite, and aplite on the west flank of the Rocky Lakes pluton of Currie (1987) exhibit several features that are atypical of Neoproterozoic granitic rocks in this area. Rapakivi textures, pegmatitic sweats, a convex exfoliation and lack of a penetrative fabric suggest they are part of the adjacent Siluro-Devonian Saint George Batholith rather than the Rocky Lakes suite. As a result, the boundary of the Saint George Batholith has been revised to a position 1-2 km further east of that shown on most previous maps (e.g. MacKenzie, 1964; McCutcheon and Ruitenberg 1987; McLeod 1990; Currie 1987, 1988, 1997), but similar to the location shown by Cherry (1976). Several small plugs of Late Devonian aplitic granite not shown on Fig. 8 intrude the Rocky Lakes suite east of the contact.

No radiometric ages exist for the Rocky Lakes suite. The intrusive rocks are more typical of the Ragged Falls suite than the Lingley suite; therefore, I have tentatively assigned a Late Neoproterozoic age to this suite.

\section{Cambrian units}

Cambrian volcanic, volcaniclastic and epiclastic rocks in the Pocologan River area were informally referred to as the Mosquito Lake Road volcanics and Matthews Lake beds by Johnson and McLeod (1996). These rocks, herein elevated to formations, occur in an elongate northeast - trending band extending from the Lake Utopia area near St. George to Robin Hood Lake, a distance of over $40 \mathrm{~km}$. The sequence ends abruptly along the north-trending Robin Hood Lake fault zone, at a marked bend in the structural trend, as discussed below.

\section{Mosquito Lake Road Formation}

The formation consists of light to dark grey, fine- to coarse-grained, lithic and feldspathic wacke, volcaniclastic wacke, laminated phyllitic siltstone and light grey sandstone, dark grey, locally graphitic slate, maroon polymictic conglomerate, and rhyolitic to basaltic volcanic rocks (Fig. 9). Dark maroon bands and lenses of strongly magnetic iron formation are relatively common in the formation (Fig 9a). The feldspathic wacke locally contains large attenuated quartzite clasts and iron-rich clasts or smeared out beds. On Mosquito Lake Road, volcaniclastic wacke in the formation has thin bands containing small garnet grains (Fig. 9b) and locally cordierite porphyroblasts in the vicinity of the Late Devonian Mount Douglas Granite. The main foliation in these rocks, evident as stretched lithic clasts as shown in Fig. 9c, trends east-northeast. The volcanic rocks consist mainly of spherulitic rhyolite flows and felsic crystal tuff and minor basalt to dacitic flows. An autoclastic rhyolite breccia occurs near the contact with the overlying Matthews Lake Formation on the Mosquito Lake Road (Fig. 9d). The base of the Mosquito Lake Road Formation is faulted so the original thickness is not known; however, the formation is at least 850 $\mathrm{m}$ thick. The upper contact is well exposed on the Mosquito Lake Road where quartzite-pebble conglomerate of the Matthews Lake Formation directly overlies rhyolite tuff and breccia.

The Mosquito Lake Road Formation was thought to be Late Cambrian age based on a U-Pb zircon date of $515+3 /-2$ Ma for rhyolitic volcanic rocks near the top of the formation (Johnson and McLeod 1996). However, using the significantly revised Cambrian time scale of McKerrow and van Staal (2000 and references therein), the Mosquito Lake Road Formation is late Early Cambrian.

\section{Matthews Lake Formation}

The Matthews Lake Formation is comprised of light grey, massive, thick-bedded, granular quartz arenite and intraformational quartzite pebble conglomerate, laminated sandstone and siltstone, volcanogenic sandstone (mafic volcanic debris), and calc-silicate rocks. Thick-bedded quartz arenite in the formation commonly contains abundant volcanic quartz. In the contact aureole of a Late Devonian phase of the Saint George Batholith, the quartzite-pebble conglomerate has a biotite-rich quartzose matrix (Fig. 10). East of Mosquito Lake Road the conglomerate rapidly thickens toward Matthews Lake and Loch Alva. To the west, the conglomerate is truncated by a fault defining the southern margin of the Early Silurian Fowle Lake Formation (Johnson and McLeod 1996). A minimum estimated thickness for the formation is approximately $500-600 \mathrm{~m}$.

West of Loch Alva, the base of the quartzite pebble conglomerate appears to be a nonconformity with underlying Neoproterozoic(?) granite of the Rocky Lakes suite. The contact is sheared and intensely quartz-veined in one outcrop but away from the fault the conglomerate appears to lie directly on granite. An intrusive contact was observed between the Matthews Lake Formation and granite on Rancliffe Creek (Fig. 8); however, the fine-grained granite at this locality resembles the Siluro-Devonian Saint George Batholith. The Matthews Lake Formation is unfossiliferous but based on its stratigraphic position with respect to the Mosquito Lake Road Formation it is no older than late Early Cambrian. McCutcheon and Ruitenberg (1987) suggested that the Matthews Lake Formation is Silurian. The fact that the quartzite-pebble conglomerate appears to overstep the Mosquito Lake Road Formation onto Neoproterozoic granite suggests an unconformity at its base. Although a Silurian age is possible, no significant hiatus appears to be present at the contact with the Lower Cambrian rhyolite, and identical laminated siltstone and sandstone are present in both formations. It is possible that the quartzite-pebble conglomerate west of Loch Alva occupies a higher stratigraphic level in the Matthews Lake Formation than that on Mosquito Lake Road.

Both the Matthews Lake and Mosquito Lake Road formations exhibit two strong foliations. The deformation within this zone is evident as flattened, stretched, and 

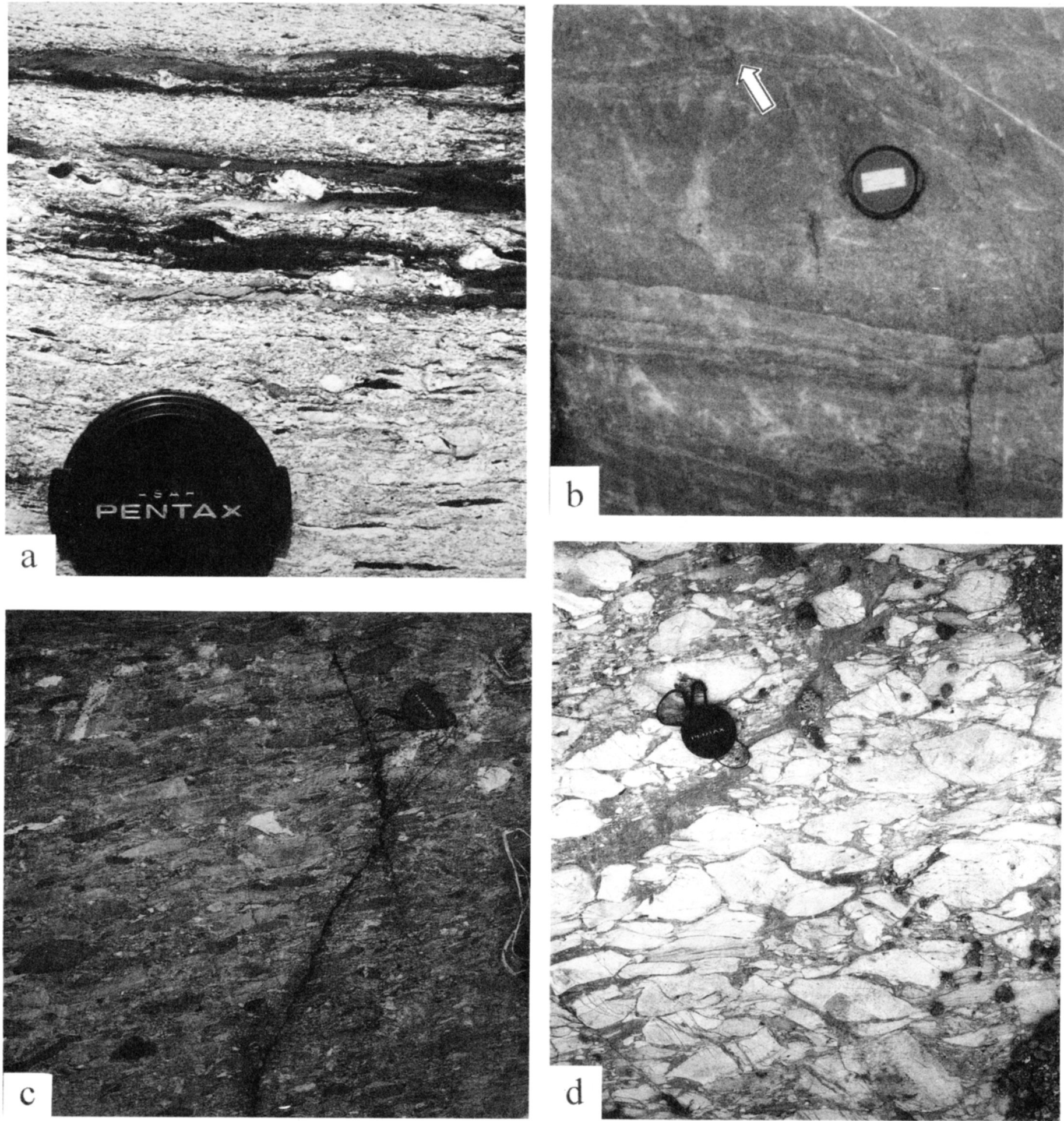

Fig. 9 Field photographs of the Mosquito Lake Road Formation. Lens cap for scale in photos. a) Volcaniclastic sandstone with iron-rich siltstone layers. b) Volcaniclastic sandstone with garnet coticule horizon (arrowed). c) Strongly foliated polymictic conglomerate. d) Rhyolite breccia.

boudinaged clasts trending east-northeast. A strongly developed northeast-trending fabric that is best seen in the finer-grained sedimentary units refolds this foliation.

\section{Correlation}

In contrast to the rocks east of the Robin Hood Lake fault, Cambrian rocks of the Mosquito Lake Road and Matthews Lake formations are not easily correlated with the Saint John Group in the Caledonia belt. The $515+3 /-2$ Ma age for the Mosquito Lake Road Formation is only slightly older than the 


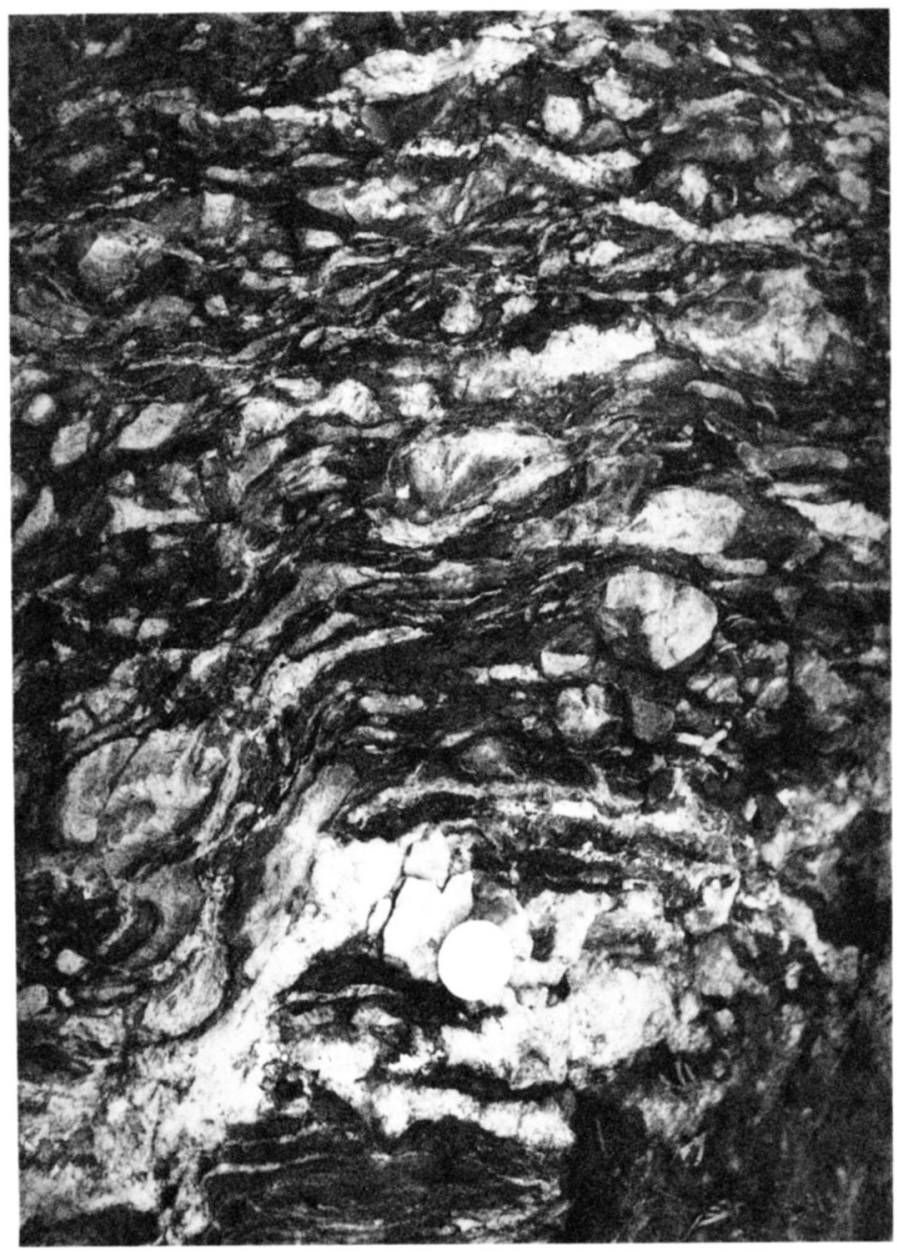

Fig. 10. Quartzite-pebble conglomerate with biotite-rich matrix, Matthews Lake Formation. Note dollar coin in bottom centre of photo for scale.

$511 \pm 1$ Ma date recently reported (Landing et al. 1998) for thin ash beds in the Hanford Brook Formation. Although member level units in the Hanford Brook Formation can be correlated from the Long Reach area to Saint John, a distance of over $25 \mathrm{~km}$ (Fig. 2), even a broad comparison between the Matthews Lake and Hanford Brook formations on opposite sides of the Robin Hood Lake fault is difficult to make. To my knowledge, thick-bedded quartzite pebble conglomerate and medium- to coarse-grained quartz arenite like that in the Matthews Lake Formation does not occur in the Hanford Brook or younger formations.

The compositionally expanded nature of the ca. $555 \mathrm{Ma}$ Ragged Falls and Rocky Lakes suites in the Pocologan River area also appears to differ from the ca. 560-550 Ma plutonic rocks in the Caledonia belt, which are clearly bimodal in their composition (Barr and White 1999). In several respects the Late Neoproterozoic and Cambrian rocks in the Pocologan River area are comparable with the Brookville belt (White and Barr 1996) and with lithologically similar rocks in Maine, as discussed below.

\section{GeOLOGY OF THE BEAVER HARBOUR AREA}

Neoproterozoic and Cambrian rocks immediately west of the Belleisle fault and east of the Letang Harbour fault in the Beaver Harbour area (Fig. 2) were included in New River belt by Johnson and McLeod (1996). Alaskite in the Blacks Harbour Granite (Helmstaedt 1968), occupies most of the area within this fault block. On Buckmans Creek the Blacks Harbour Granite is unconformably overlain by a succession of mafic breccia, nodular limestone, and siliciclastic mudstone informally referred to as the Buckmans Creek beds (Currie 1988). The Buckmans Creek beds contain Middle Cambrian (P. bennetti zone) trilobites (Helmstaedt 1968; Greenough et al. 1985). Landing's (1996, p. 48) preliminary assessment of the Buckmans Creek fauna suggests that the assemblage is correlative with the upper Chamberlains Brook - Manuels River interval of the Avalonian cover sequence. The upper Chamberlains Brook and Manuels River formations are lithologically comparable and time equivalent to the Forest Hills Formation in the Saint John area, and are referred to as such by Landing (1996, Fig. 5 and p. 46). The lack of volcanic rocks in the Forest Hills Formation is attributed to the localization of volcanic activity within transtensional subbasins (Greenough et al. 1985; Greenough and Papezik 1986; Landing and Westrop 1998; Landing 1996).

\section{Discussion}

The Robin Hood Lake fault zone marks the site of important changes in both the basement and cover rocks that have not been fully recognized in the past. The Pocologan River and Long Reach areas, on opposite sides of this fault, are underlain by lithologically distinct Cambrian sequences and Neoproterozoic granitoid rocks of vastly different ages. Currie $(1988$, p. 347$)$ noted that mylonitic fabrics, which are common in the New River belt west of the Robin Hood Lake fault, end abruptly at this structure, although he did not make any lithological distinction between units across this fault. The faulted boundary between the Pocologan and Long Reach sequences is not exposed but is defined by a chain of lakes extending from Loch Alva to Robin Hood Lake where there is an abrupt change in the regional structural trend from northeast to north (Fig. 2). East of the main fault trace is a wide zone $(>1.5 \mathrm{~km})$ containing several parallel north-trending faults bounding intensely cataclased rocks. The eastern end of the fault zone is more diffuse gradually diminishing into the plutonic rocks of the Lingley suite.

The Robin Hood Lake fault appears to be truncated by the latest significant movement on the northeast-trending Wheaton Brook and Belleisle faults, which mark the northwestern and southeastern limit of Neoproterozoic and Cambrian rocks in the Long Reach area. In essence, the stratigraphic succession that characterizes the Long Reach area is confined to a fault wedge along the western side of the Belleisle fault. The Beaver Harbour area is considered to occupy a similar fault sliver along the Belleisle fault to the southwest. The Belleisle fault is a regional scale structure with a long and complex history of movement, including major dextral strike-slip movement in the Carboniferous (Webb 
1963, 1969; Brown and Helmstaedt 1970; Currie 1984; Leger 1986).

The contrast between Cambrian rocks on either side of the Robin Hood Lake fault indicates that the New River and Long Reach segments were juxtaposed after deposition of the Latest Neoproterozoic to Early Ordovician Avalonian cover sequence. Emplacement of the Long Reach segment prior to Late Devonian time is suggested by an unconformity between granitoid rocks of the Lingley suite and the DevonoCarboniferous Sagwa conglomerate. Evidence for major northwest-directed thrusting on the Wheaton Brook fault (McCutcheon 1981) was disputed by Currie $(1984,1988)$. The latter author suggested that juxtaposition of hornfelsed Late Silurian rocks with relatively unmetamorphosed Neoproterozoic and Cambrian rocks east of the Wheaton Brook fault was more indicative of major transcurrent movement. However, the very intense shallow, south-dipping penetrative fabric in the Lingley suite adjacent to this fault indicates a thrust component at some time during its history. The main trace of the Wheaton Brook fault appears to be intruded by the Late Devonian Mount Douglas Granite, thereby suggesting that the composite New River belt was assembled sometime after the Late Silurian and prior to the Late Devonian.

The lithological correlation of units in the Long Reach and Saint John areas demonstrates that the northeastern part of the New River belt was attached to the Caledonia belt (Avalon zone sensu stricto) during Late Neoproterozoic and Cambrian time. Although Landing et al. (1998, p. 336) consider the Mosquito Lake Road Formation to be part of a late Early Cambrian to Middle Cambrian extensional event in Avalon, I believe that it differs in many respects from the bimodal volcanic rocks found elsewhere in the cover sequence. With the exception of the Early Cambrian Mosquito Lake Formation, all of the other volcanic sequences in the Avalonian cover sequence of Maritime Canada are Middle Cambrian (Greenough et al. 1985: Greenough and Papezik 1986; White et al. 1994; Landing and Murphy 1991; Landing and Westrop 1998).

For example, Middle Cambrian fossils within the mafic volcanic and sedimentary sequence at Beaver Harbour indicate a correlation with bimodal volcanic rocks in the Bourinot belt (northern Boisdale Hills) of Cape Breton and southern Trinity and western St. Mary's Bays of Newfoundland (Landing 1996; Landing and Westrop 1998). A U-Pb date for rhyolite from the northern Boisdale Hills is $505 \pm 3 \mathrm{Ma}$ (White et al. 1994), therefore, significantly younger than the Mosquito Lake Road Formation $(515+3 /-2 \mathrm{Ma})$. A post-Early Cambrian age is also suggested for Cambrian volcanic and associated sedimentary rocks in the Antigonish Highlands (Landing and Murphy 1991; Murphy et al. 1985). With the exception of the Mosquito Lake Road Formation, all of these Cambrian volcanic sequences are correlated with depositional sequences 6 to 8 of the cover sequence (Landing and Westrop 1998; Landing 1996). The Mosquito Lake Road Formation is contemporaneous with the terminal stages of depositional sequence 2-4 unconformity; therefore, it contains the only Early Cambrian volcanic rocks within this "group".
A distinction may also be made based on geochemistry of the volcanic rocks. The within-plate character of Middle Cambrian volcanic rocks in the Avalon zone is well documented in Maritime Canada (Greenough et al. 1985; Greenough and Papezik 1986; White et al. 1994 and references therein). In contrast, Johnson and McLeod (1996) showed that the Mosquito Lake Road volcanic rocks appear to be geochemically related to subduction processes.

It is also interesting that the late Early to Middle Cambrian(?) quartzite and conglomerate of the Matthews Lake Formation is lithologically more akin to rocks in the St. Croix belt than to those in the Caledonia belt. Thick-bedded, light grey to white quartzite and quartzite-pebble conglomerate in the Battie Quartzite member at the base of the Middle Cambrian Megunticook Formation (Berry and Osberg 1989; Tucker et al. 2001) is strikingly similar to the Matthews Lake Formation (Johnson 2001 a). Overlying the basal quartzite and conglomerate, the Megunticook Formation is mainly comprised of quartz-mica schist, typically containing small garnet, calc-silicate rocks, chiastolitic quartz-biotite schist, and thin bedded quartzite and schistose quartz-plagioclase-mica granofels (Berry and Osberg 1989; Tucker et al. 2001). The Megunticook Formation conformably underlies the Penobscott Formation for which a U-Pb zircon age of $503 \pm 5 \mathrm{Ma}$ (late Middle Cambrian) is reported for a fragmental felsic tuff near the base (Osberg et al. 1995; Tucker et al. 2001). Therefore, the Megunticook Formation may be comparable in age to the Matthews Lake Formation.

Though a possible lithological correlation can be made between the Matthews Lake and Megunticook formations, the Mosquito Lake Road Formation appears to have no direct correlatives in the St. Croix belt or adjacent Ellsworth belt in Maine (Berry and Osberg 1989). Cambrian felsic volcanic rocks are found in the Ellsworth belt but they are, at least in part, younger than the Mosquito Lake Road Formation. Cambrian ages obtained from the Ellsworth belt in Maine include $509 \pm 1 \mathrm{Ma}$ for the Ellsworth Schist (Stewart et al. 1995 ) and $503 \pm 4 \mathrm{Ma}$ and $501.9 \pm 4 \mathrm{Ma}$ (Ruitenberg et al. 1993; Stewart et al. 1995) for the overlying Castine Volcanics. The latter ages are virtually identical to those obtained from volcanic rocks in the Annidale Group in the northeastern part of the St. Croix belt in New Brunswick (Ruitenberg el al. 1993; McLeod et al. 1992; M. McLeod, unpublished data) and in the St. Croix belt in Maine (Osberg et al. 1995).

\section{TECTONIC CONSIDERATIONS}

Although the New River belt is comprised of structurally juxtaposed segments with unique stratigraphies, the tectonic significance of these differences needs to be considered. It has been proposed that all Neoproterozoic rocks west of the Caledonia belt in the Saint John area, essentially the Brookville and New River belts (Fig. 1), comprise a continental fragment (s) that developed separately from the Avalon zone (sensu stricto) during the Late Neoproterozoic and Early Paleozoic (e.g. Barr and White 1996a, 200la: Johnson and McLeod 1996; Fyffe et al. 1999). The presence of Caledonia belt equivalents in the Long Reach area is 
potentially problematic in this model, although it could be explained by complex strike-slip and/or reverse faulting after collision. Alternatively, others consider all Neoproterozoic rocks in southern New Brunswick, essentially the Caledonia, Brookville and New River belts, to be part of one continental block referred to as Avalon (e.g. Currie 1988; Landing 1996; Currie and McNicoll 1999). The definition generally used by these authors is that Avalon was a unified continent during, but not necessarily before, deposition of the Latest Neoproterozoic to Early Ordovician Avalonian cover sequence.

In the author's opinion, the recent recognition of significant unconformities throughout the Avalonian cover sequence and the interpretation of its depositional setting on an epeirogenically active platform (Landing 1996; Landing and Westrop 1998) are of considerable importance to the single- versus multi-terrane argument. One of the prime reasons for challenging the Avalonian affinity of the New River and other suspect belts in southern New Brunswick was the presumption that strata of the cover sequence were deposited, essentially without interruption, in a passively subsiding basin, leaving no room for contemporaneous tectonothermal activity.

Although ca. 555-550 Ma magmatic activity characterizes all Neoproterozoic belts in southern New Brunswick, their relationship during this period remains controversial due to conflicting interpretations for the tectonic setting of these rocks (compare Whalen et al. 1994: White 1996; White and Barr 1996). However, muscovite ages from metamorphic rocks interpreted to be a fragment of an accretionary wedge on the northwest margin of the Caledonia belt (White et al. 2001) strongly suggest that the Caledonia belt collided with some other block (the now adjacent Brookville belt ?) prior to the onset of deposition of the Avalonian cover sequence. ${ }^{40} \mathrm{Ar} /{ }^{39} \mathrm{Ar}$ ages for these metamorphic rocks are virtually identical to ca. 610-620 Ma detrital muscovite ages from Early Cambrian rocks in the cover sequence (Dallmeyer and Nance 1990), suggesting that the former provided detritus to sedimentary rocks in the Caledonia belt (White et al. 2001).

A possible link between the Brookville and New River belts is also suggested in late Early Cambrian time. Early Cambrian volcanic activity in the New River belt is coeval with a major ca. 520-511 Ma thermal event in the Brookville belt (Dallmeyer and Nance 1992; White 1996; Currie and McNicoll 1999). This magmatic activity is also coincident with a period of basin reorganization and tectonic activity within the Avalonian cover sequence during the Early Cambrian in the Caledonia belt. The latter is characterized by a significant unconformity between the early Early Cambrian Glen Falls Formation (Random Formation of Landing and Westrop 1998) and the latest Early Cambrian Hanford Brook Formation (Landing and Westrop 1998) in the Saint John Group. U-Pb zircon ages from volcanic ash beds roughly $<20$ $\mathrm{m}$ below and $<50 \mathrm{~m}$ above the unconformity bracket the hiatus between ca. $531 \mathrm{Ma}$ and ca. $511 \mathrm{Ma}$ (Isachsen et al. 1994; Landing et al. 1998). Although the significance of these unconformities and their relationship to tectonic activity in the New River and Brookville belts is debatable, I believe it adds credence to the idea that the Late Neoproterozoic and Early Paleozoic tectonic history of the Caledonia, Brookville and New River belts is not necessarily incompatible.

It is also noteworthy that all of the occurrences of Saint John Group rocks in the Brookville belt, albeit in faulted slivers, are assigned to the latest Early Cambrian Hanford Brook or younger formations (White 1996; Landing and Westrop 1996). These formations essentially post-date magmatic activity in the Brookville belt, making it possible that the Saint John Group represents stratigraphic cover rather than tectonic cover to the Brookville belt, as advocated in the multi-terrane model. The Brookville belt may represent elevated parts of the Avalon platform that were subsequently onlapped by late Early Cambrian or younger rocks of the cover sequence, similar to the Bras d'Or belt on Cape Breton Island (Landing 1996, p. 43).

Nonetheless, Early Cambrian plutonic ages (ca. 545-530 $\mathrm{Ma}$ ) in the Brookville belt (White 1996; Currie and Hunt 1991; Currie and McNicoll 1999; Barr et al. 2001a) demonstrate that at least some of this magmatic activity is contemporaneous with alluvial to shallow marine rocks of the lower Saint John Group. Although it is possible that these differences signify that the Brookville and Caledonia belts were distinct continental blocks in the Cambrian, used with the above information, they could also be explained by wide geographic separation on one continental block during deposition of the Saint John Group. Large-scale strike-slip faulting over a prolonged period of time would be responsible for the present adjacent position of these once widely separated belts. A progressively eastward shift in Cambrian depocentres within Avalon (Landing and Westrop 1998, p. 7) suggests that transtensional motion began in Cambrian time. This movement followed by strike-slip faulting that continued into the Carboniferous (e.g. Currie 1984; Leger 1986) was probably responsible for the present configuration of belts in southern New Brunswick.

If the single terrane model is correct, the correlation of the Matthews Lake Formation with rocks in the St. Croix belt evokes Ludman's (1986) interpretation of the Saint John Group and St. Croix belt as shelf and basinal equivalents of the same terrane. It also supports the proposal by Tucker et al. (2001) that the stratigraphy of the St. Croix belt in Maine is comparable with that of "Composite Avalon". There are still many unanswered questions and it remains to be seen if St. Croix belt strata are also related to lithologically similar rocks in the Gander zone, as suggested by some workers (e.g. Fyffe and Pickerill 1986; van Staal and Fyffe 1991, 1995).

\section{ACKNOWLEDGEMENTS}

Many thanks to Cees van Staal and Dave Stewart for their critical reviews which led to significant improvements in the paper and to Les Fyffe for his helpful comments on an earlier version of the paper. I thank Malcolm McLeod, Sandra Barr. and Chris White for many fruitful discussions on southern New Brunswick geology and Maurice Mazerolle for his patience and expertise with the diagrams. Funding for the mapping was provided by the New Brunswick Department of 
Natural Resources and Energy.

\section{REFERENCES}

ALCOCK, F.J. 1938. Geology of Saint John region, New Brunswick. Geological Survey of Canada, Memoir 216, 65 p.

BARR, S.M., \& WHITE, C.E. 1996a. Contrasts in late Precambrian-early Paleozoic tectonothermal history between Avalon composite terrane sensu stricto and other possible peri-Gondwanan terranes in southern New Brunswick and Cape Breton Island, Canada. In Avalonian and Related Peri-Gondwanan Terranes of the CircumNorth Atlantic. Edited by R.D. Nance and M.D. Thompson. Geological Society of America, Special Paper 304, pp. 95-108.

BARR, S.M., \& WHITE, C.E. 1996b. Tectonic setting of Avalonian volcanic and plutonic rocks in the Caledonian Highlands, southern New Brunswick. Canada. Canadian Journal of Earth Science, 33, pp. 156-168.

BARR, S.M., \& WHITE, C.E. 1999. Field relations, petrology and structure of Neoproterozoic rocks in the Caledonian Highlands, Southern New Brunswick. Geological Survey of Canada Bulletin, $530,101 \mathrm{p}$.

BARR, S.M., \& WhITE, C.E. 2001a. Terranes in the Pocologan area, southern New Brunswick. In Guidebook to Field Trips in New Brunswick and western Maine. Edited by R.K. Pickerill and D. Lentz. New England Intercollegiate Geological Conference, pp. B2-1-B2-14.

BARR, S.M., \& WHITE, C.E. 2001b. The Kingston Group: a redefined Silurian stratigraphic unit in southern New Brunswick. In Current Research 2000. Edited by B.M.W Carroll. New Brunswick Department of Natural Resources and Energy, Minerals and Energy Division, Mineral Resource Report 2001-4, pp. 1-14.

BARR, S.M., BEvieR, M.L.. WhITE, C.E., \& DoIG, R. 1994. Magmatic history of the Avalon Terrane of southern New Brunswick, Canada, based on U-Pb (zircon) geochronology. Journal of Geology, 102, pp. 399-409.

BARR, S.M., WHITE, C.E., \& MCLEOD, M.J. 1999. Geology of the Silurian Kingston Terrane, southern New Brunswick. In Current Research 1998. Edited by B.M.W. Carroll. New Brunswick Department of Natural Resources and Energy, Minerals and Energy Division, Mineral Resources Report, 99-4, pp. 1-17.

BARR, S.M., WhITE, C.E., \& Miller, B.V. 2001. Cambrian granitoid plutons of the Pocologan area and the continuation of the Brookville belt to the Wolves Islands. In Current Research 2000. Edited by B.M.W. Carroll. New Brunswick Department of Natural Resources and Energy, Minerals and Energy Division, Mineral Resources Report, 2001-4, pp. 15-24.

BERRY, H.N.. \& OSBERG, P.H. 1989. A stratigraphic synthesis of eastern Maine and western New Brunswick. In Studies in Maine Geology. Edited by R. D. Tucker and R.G. Marvinney. Maine Geological Survey, Department of Conservation, Volume 2: Structure and Stratigraphy, pp. 1-32.

BROWN, R.L., \& HELMSTAEDT, H. 1970. Deformation history in part of the Lubec-Belleisle zone of southern New Brunswick. Canadian Journal of Earth Sciences, 7, pp. 748-767.

BEVIER, M.L., \& BARR, S.M. 1990. U-Pb age constraints on the stratigraphy and tectonic history of the Avalon Terrane, New Brunswick, Canada. Journal of Geology, 98, pp. 53-63.

CHERRY, M.E. 1976. The petrogenesis of granites in the St. George batholith, southwestern New Brunswick. Unpublished Ph.D. thesis, University of New Brunswick, Fredericton, New Brunswick, $242 \mathrm{p}$.

COPELAND, M.J. 1889. A redescription of Ceratiocaris pusilla Matthew. Journal of Paleontology, 31, pp. 600-602.
CURRIE, K.L. 1984. A reconsideration of some geological relations near Saint John, New Brunswick. In Current Research, Part A. Geological Survey of Canada, Paper 84-1A, pp. 193-201.

CuRRIE, K.L. 1987. Late Precambrian igneous activity and its tectonic implications, Musquash-Loch Alva region, southern New Brunswick. In Current Research, Part A. Geological Survey of Canada, Paper 87-1 A, pp. 663-671.

CURRIE, K.L. 1988. The western end of the Avalon Zone in southern New Brunswick. Maritime Sediments and Atlantic Geology, 24, pp. 339-352.

CURRIE, K.L. 1992. The "Lorneville Beds": a latest Precambrian sequence near Saint John, New Brunswick. In Current Research, Part D. Geological Survey of Canada, Paper 92-1D, pp. 35-43.

CURRIE, K.L. 1997. Geological map of the Saint John - Saint George region (with marginal notes). Geological Survey of Canada, Open File Report 3418.

CURRIE, K.L., \& HUNT, P.A. 1991. Latest Precambrian igneous activity near Saint John, New Brunswick. In Radiogenic Age and Isotopic Studies: Report 4. Geological Survey of Canada, Paper 90-2, pp. 11-17.

CURRIE, K.L., \& MCNiCOLL, V.J. 1999. New data on the age and geographic distribution of Neoproterozoic plutons near Saint John, New Brunswick. Atlantic Geology 35, pp. 157-166.

DALlMEYER, R.D., \& NANCE, R.D. 1990. Ar/Ar ages of detrital muscovite within early Paleozoic overstep sequences, Avalon composite terrane, southern New Brunswick. Canadian Journal of Earth Sciences, 27, pp. 1209-1214.

DAllmeYER, R.D., \& NANCE, R.D. 1992. Tectonic implication of ${ }^{40} \mathrm{Ar}{ }^{39} /$ Ar mineral ages for Late Precambrian - Cambrian plutons, Avalon composite terrane, southern New Brunswick, Canada. Canadian Journal of Earth Sciences, 29, pp. 2445-2462.

FYFFE, L.R., \& PICKERILL, R.K. 1986. Comment and reply on "Timing of terrane accretion in eastern and east-central Maine. Geology, 14, p. 1051-1052.

FyfFE, L.R., PICKerLll, R.K., \& Stringer, P. 1999. Stratigraphy, sedimentology and structure of the Oak Bay and Waweig formations, Mascarene Basin: implications for the paleotectonic evolution of southwestern New Brunswick. Atlantic Geology, 35, pp. 59-84.

GREENOUGH, J.D., \& PAPEZIK, V.S. 1986. Acado-Baltic volcanism in eastern North America and western Europe: implications for Cambrian tectonism. Maritime Sediments and Atlantic Geology, 22, pp. 240-251.

GREenough, J.D., MCCUTCHEON, S.R., \& PAPEZIK, V.S. 1985. Petrology and geochemistry of Cambrian volcanic rocks from the Avalon Zone in New Brunswick. Canadian Journal of Earth Sciences, 22, pp. 881-892.

Hayes, A.O., \& HOWELl, B.F. 1937. Geology of Saint John, New Brunswick. Geological Society of America, Special Paper 5, 146 p.

HELMSTAEDT, H. 1968. Structural analysis of the Beaver Harbour area, Charlotte County, New Brunswick. Unpublished Ph.D. thesis, University of New Brunswick, Fredericton. New Brunswick, $196 \mathrm{p}$.

ISACHSEN, C. E., BOWRING, S.A., LANDING, E., \& SAMSON, S.D. 1994. New Constraint on the division of Cambrian time. Geology, 22, pp. 496-498.

JOHNSON, S.C. 2000. Bedrock geology of the Long Reach area. New Brunswick Department of Natural Resources and Energy, Mineral and Energy Division, Plate 2000-17.

JOHNSON, S.C. 2001 a. The New River Terrane revisited: insights into the relationship with the St. Croix and Ellsworth terranes in New Brunswick and Maine. In Program and Abstracts. Edited by M. Parkhill. Atlantic Geoscience Society, Colloquium and Annual General Meeting, pp. 19-20. 
JOHNSON, S.C. 2001b. Stratigraphy of Neoproterozoic and Devonian - Carboniferous volcanic and epiclastic rocks in the Long Reach and Taylors Island areas, New Brunswick. In, Guidebook to Field Trips in New Brunswick and western Maine. Edited by R.K. Pickerill and D. Lentz. New England Intercollegiate Geological Conference, pp. A2-1 - A2-15.

JOHNSON, S.C., \& MCLEOD, M.J. 1996. The New River belt: A unique segment along the western margin of the Avalon composite terrane, southern New Brunswick. In Avalonian and Related Peri-Gondwanan Terranes of the Circum-North Atlantic. Edited by R.D. Nance and M.D. Thompson. Geological Society of America, Special Paper 304, pp. 149-164.

LANDING, E. 1996. Avalon: insular continent by the latest Precambrian. In Avalonian and Related Peri-Gondwanan Terranes of the Circum-North Atlantic. Edited by R.D. Nance and M.D. Thompson. Geological Society of America, Special Paper 304, pp. 29-62.

LANDING, E \& MURPhY, J.B. 1991. Uppermost Precambrian (?) Lower Cambrian of mainland Nova Scotia: faunas, depositional environments and stratigraphic revisions. Journal of Paleontology, 65, pp. 382-396.

LANDING, E., \& WESTROP, S.R. 1996. Upper Lower Cambrian depositional sequence in Avalonian New Brunswick. Canadian Journal of Earth Sciences, 33, pp. 404-417.

LANDING, E., \& WESTROP, S.R. 1998. Avalon 1997- The Cambrian Standard. Third international field conference of the Cambrian chronostratigraphy working group and I.G.C.P. Project 366. New York State Bulletin 492, 92 p.

LANDING, E., Bowring, S.A., DA VIDEK, K.L., Westrop, S.R., GeYER, G., \& HelDMAIER, W. 1998. Duration of the Early Cambrian: U$\mathrm{Pb}$ ages of volcanic ashes from Avalon and Gondwana. Canadian Journal of Earth Sciences, 35, pp. 329-338.

LEGER, A. 1986. Transcurrent faulting history of southern New Brunswick. Unpublished M.Sc. thesis, University of New Brunswick, Fredericton, New Brunswick, 170 p.

LUDMAN, A. 1986. Timing of terrane accretion in eastern and eastcentral Maine. Geology, 14, pp. 411-414.

MacKenZIE, G.S. 1964. Geology of Saint John, New Brunswick. Geological Survey of Canada, Map 1113A (with marginal notes).

MATTHEW, G.F. 1886. Illustrations of the fauna of the St. John Group continued. No. 3. -Descriptions of new genera and species (including a description of a new species of Solenopleura by J.F. Whiteaves). Transactions of the Royal Society of Canada, 4, pp. $29-84$.

Matthew, G.F. 1890 . On Cambrian organisms in Acadia. Transactions of the Royal Society of Canada, 7, pp. 135-143.

MATTHEW, G.F. 1891. Illustrations of the fauna of the Saint John Group No V (5). Transactions of the Royal Society of Canada, 8, pp. 123-166.

MCCUTCHEON, S.R. 1981. Revised stratigraphy of the Long Reach area, southem New Brunswick: Evidence for major, northwestward-directed Acadian thrusting. Canadian Journal of Earth Sciences, 18, pp. 646-656.

MCCUTCHEON, S.R., \& RUITENBERG, A.A. 1987. Geology and mineral deposits, Annidale-Nerepis area, New Brunswick. New Brunswick Department of Natural Resources and Energy, Mineral Resources Division, Memoir 2, 141 p.

McKerrow, W.S., \& van StAal, C.R. 2000. The Paleozoic time scale reviewed. In Orogenic Processes: Quantification and Modelling in the Variscan belt. Edited by W. Franke, V. Haak, O. Oncken and D. Tanner. Geological Society, London, Special Publications, 179, pp. 5-8.

MCLEOD, M.J. 1990. Geology, geochemistry, and related mineral deposits of the Saint George Batholith; Charlotte, Queens, and
Kings counties, New Brunswick. New Brunswick Department of Natural Resources and Energy, Mineral Resource Report 5, 169 p.

MCLEOD, M.J., RUITENBERG, A.A., \& KROGH, T.E. 1992. Geology and $\mathrm{U}-\mathrm{Pb}$ geochronology of the Annidale Group, southern New Brunswick: Lower Ordovician volcanic and sedimentary rocks formed near the southeastern margin of Iapetus Ocean. Atlantic Geology, 28, pp. 181-192.

MuRPhy, J.B., KEPPIE, J.D., DOSTAL, J., \& HYNES, A.J. 1985. Cambrian volcanism in Nova Scotia, Canada. Canadian Journal of Earth Sciences, 22, pp. 599-606

OSBERG, P.H., TUCKER, R.D., \& BERRY, H.N. 1995. Is the Acadian suture lost? In Guidebook to Fieldtrips in southern Maine and adjacent New Hampshire. Edited by A.M. Hussey II and R.A. Johnston. New England Intercollegiate Geological Conference, Trip B-2, pp. B2-1-B2-27.

Rast, N., Grant, R.H., Parker, J.S.D., \& TENG, H.C. 1978. The Carboniferous deformed rocks west of Saint John, New Brunswick. In Guidebook for Field Trips in Southeastern Maine and Southwestern New Brunswick, Edited by A. Ludman. 70th Annual Meeting New England Intercollegiate Geological Conference, Trip B6, pp. 162-173.

Ruttenberg, A.A., Giles, P.S., Venugopal, D.V., Buttmer, S.M., MCCUTCHEON, S.R., \& CHANDRA, J. 1979. Geology and mineral deposits, Caledonia area. New Brunswick Department of Natural Resources, Mineral Resources Branch, Memoir 1, 213p.

RUITENBERG, A.A., MCLEOD, M.J., \& KROGH, T.E. 1993. Comparative metallogeny of Ordovician volcanic and sedimentary rocks in the Annidale-Shannon (New Brunswick) and Harborside-Blue Hill (Maine) areas: implications of new U-Pb age dates. Exploration and Mining Geology, 2, No. 4, pp. 355-365.

Stewart, D.B., TUCKER, R.D., \& WEST, D.P. 1995. Genesis of Silurian Composite Terrane in Northern Penobscot Bay. In Guidebook to Fieldtrips in southern Maine and adjacent New Hampshire. Edited by A.M. Hussey II and R.A. Johnston. New England Intercollegiate Geological Conference, Trip A-3, pp. 29-49.

TANOLI, S.K. 1987. Stratigraphy, sedimentology and ichnology of the Cambrian-Ordovician Saint John Group, southern New Brunswick, Canada. Unpublished Ph.D. thesis, University of New Brunswick, Fredericton, New Brunswick, 2 volumes, 438p.

TANOLI, S.K., \& PICKERILL, R.K. 1988. Lithostratigraphy of the Cambrian-Lower Ordovician Saint John Group, southern New Brunswick. Canadian Journal of Earth Sciences, 25, pp. 669-690.

TUCKER, R.D., OSBERG, P.H., \& BERRY IV, H.N. 2001. The geology of a part of Acadia and the nature of the Acadian Orogeny across central and eastern Maine. American Joumal of Science, 301, pp. 205-260.

TURNER, S. 1986. Thelodus Macintoshi Stetson 1928, the largest known Thelodont (Agnatha: Thelodonti). Museum of Comparative Zoology, Cambridge, Massachusetts, Breviora. No. 486, pp. 2-18.

van StaAl, C.R., \& FYFFE, L.R. 1991. Dunnage and Gander zones. New Brunswick: Canadian Appalachian Region. New Brunswick Department of Natural Resources and Energy, Mineral Resources, Geoscience Report 91-2, 39 p.

VAN StaAl, C.R., \& FyFFE, L.R. 1995. Gander Zone -. New Brunswick. In Geology of the Appalachian - Caledonian orogen in Canada and Greenland. Edited by H. Williams. Geolngical Survey of Canada, Geology of Canada, 6, pp. 216-223.

WEBB, G.W. 1963. Occurrence and exploration significance of strike-slip faults in southern New Brunswick, Canada. American Association of Petroleum Geologists Bulletin, 47, pp. 1904-1927.

WEBB, G.W. 1969. Paleozoic wrench faults in Canadian Appalachians. In North Atlantic-Geology and Continental Drift. Edited by M. 
Kay. American Association of Petroleum Geologists, Memoir 12, pp. 754-788.

WESTROP, S.R., \& LANDING, E. 2000. Lower Cambrian (Branchian) trilobites and biostratigraphy of the Hanford Brook Formation, southern New Brunswick. Journal of Paleontology, 74, pp. 858878.

Whalen, J.B., JenNer, G.A., CuRrIe, K.L., BarR, S.M., LONGSTAFFE, F.J., \& HeGNER, E. 1994. Geochemical and isotopic characteristics of granitoids of the Avalon Zone, southern New Brunswick: Possible evidence for repeated delamination events. Journal of Geology, 102, pp. 269-282.

WHITE, C.E. 1996. Geology, geochronology, and tectonic evolution of the Brookville belt, southern New Brunswick. Unpublished Ph.D. thesis, Dalhousie University, Halifax, Nova Scotia, 513 p.

WhITE, C.E., \& BARR, S.M. 1996. Geology of the Brookville belt, southern New Brunswick, Canada. In Avalonian and Related peri-Gondwanan Terranes of the Circum-North Atlantic. Edited by R.D. Nance and M.D. Thompson. Geological Society of America, Special Paper 304, pp. 133-147.

WhITE, C.E., BARR, S.M., BeVIER, M.L., \& KAMO, S. 1994. A revised interpretation of Cambrian and Ordovician rocks in the Bourinot belt of central Cape Breton Island, Nova Scotia. Atlantic Geology, 30, pp. 123-142.

White, C.E., BARR, S.M., Jamieson, R.A., \& Reynolds, P.H., 2001. Neoproterozoic high-pressure/low temperature metamorphic rocks in the Avalon terrane, southern New Brunswick. Journal of Metamorphic Geology, 19, pp. 517-528.

Yoon, T.N. 1970. The Cambrian and Lower Ordovician stratigraphy of the Saint John area, New Brunswick. Unpublished M.Sc. thesis, University of New Brunswick, Fredericton, New Brunswick, 92 p.

Editorial responsibility: Sandra M. Barr 